\title{
Technology-sourcing investment abroad as an enhancer of Chinese MNEs' innovative capabilities
}

\author{
Philippe Gugler and Laura Vanoli \\ Center for Competitiveness, University of Fribourg, Fribourg, Switzerland
}

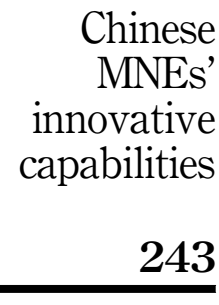

Received 18 December 2014 Revised 18 December 2014 Accepted 18 December 2014

\begin{abstract}
Purpose - The purpose of this paper is to focus on Chinese firms' innovation processes that are induced by foreign direct investment abroad. The study uses a patent and citation analysis to examine the extent to which investments abroad contribute to enhancing these firms' innovative capabilities. More specifically, this study focusses on the role of foreign location competitiveness as an asset to provide technological capabilities to Chinese affiliates.

Design/methodology/approach - Patents are good indicators of firms' innovative capabilities. Moreover, patents allow to track the inter-firm knowledge transfer through the citations of patents on which they are based. The authors use an OECD patent database called "OECD REGPAT July 2013" that compiles patents registered with the European Patent Office (EPO) over the period from 1986 to 2013. The authors focus the analysis on patents registered by Chinese multinational enterprises' (MNEs) based in Europe because the authors assume inter alia that innovations patented by Chinese affiliates in Europe are registered with the EPO. The sample comprises 3,010 patents involving 5,749 citations that the authors have individually examined.

Findings - The findings suggest that Chinese MNEs ability to generate innovation based on their own knowledge is low, with a self-citation rate of approximately 4 percent. Patents by Chinese MNEs are largely based on foreign patents, especially from developed economies (at least 90 percent). The citation analysis also suggests that 39.2 percent of citations represent domestic firms in the local recipient country. This subgroup of citations is categorized as follows: 1.04 percent are M\&A linkages, 13.8 percent are cluster linkages, and 24.36 percent are localization linkages. The remaining 60.8 percent of the total sample demonstrates that firms do not necessarily need to be collocated in foreign locations with domestic firms to exchange assets.

Research limitations/implications - Patent and citation analysis considers only a part of the interfirm knowledge diffusion. Some innovations are not patented and tacit knowledge diffusion is not observable. Moreover, the analysis focusses only on Chinese outward foreign direct investment to Europe, but a large part of knowledge is accumulated in China thanks to inward foreign direct investment. Originality/value - Many scholars have scrutinized emerging markets multinational enterprises' strategic asset-seeking investments abroad that are designed to upgrade the companies' technological capabilities (Cui and Jiang, 2009; Zhang and Filippov, 2009; Huang and Wang, 2013; Amighini et al., 2014; De Beule et al., 2014; Nicolas, 2014). However, few studies analyze the results of these strategies in terms of innovation output.
\end{abstract}

Keywords Knowledge transfer, Chinese multinational firms, Business networks

Paper type Research paper

\section{Introduction}

China is one of the leading "emerging markets" that play an increasingly important role in the world economy. Until now, Chinese competitiveness has relied largely on inexpensive labor costs, and Chinese firms are mainly active in mature markets characterized by "standardized technologies" (Wang et al., 2012, p. 434). According to the World Economic Forum (WEF) classification, China belongs to the group of

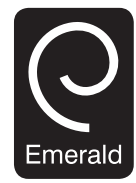

International Journal of Emerging Markets

Vol. 10 No. 2, 2015 pp. $243-271$

(c) Emerald Group Publishing Limited DOI 10.1108/IJOEM-12-2014-0217 
IJOEM

10,2

countries characterized by an "efficiency-driven stage of development" (WEF, 2013, p. 10). The country is still a long way away from joining the cohort of the so-called "innovation-driven economies," according to the WEF classification (Nolan, 2001). As indicated by Deng (2007), Chinese firms' innovative capabilities are quite weak, reflecting the country's poor domestic "innovation system" (p. 77). Thanks to international activities and links with foreign firms, Chinese firms are in the process of enhancing their technological capabilities. For example, Wang et al. have identified positive relations between external technology acquisitions (e.g. through licensing agreements) and Chinese firms' performance (Wang et al., 2013, p. 1082). Earlier studies have also addressed the role of trade and investment flows to acquire new knowledge and innovative capacities (Wei and Liu, 2006; Guan et al., 2006; Liu and Buck, 2007).

In this respect, inward and outward foreign direct investment (IFDI and OFDI, respectively) may play a significant role in strengthening the innovative capabilities of Chinese firms. China has been among the main recipient countries of FDI and among the main investors abroad over the last few years (UNCTAD, 2013, pp. 3-6). In 2012, China jumped from 6 th to 3 rd place as the largest investor (annual flows) after the USA and Japan (UNCTAD, 2013, p. xiii). Although Chinese OFDI stocks are still limited, China is expected to be one of the major investors in the near future (Wu and $\mathrm{Chen}$, 2001; Alon et al., 2010, p. 14; UNCTAD, 2013, p. 21). Many early studies on Chinese OFDI have highlighted the fact that most Chinese investors abroad were mainly market seekers and resource seekers (Alon et al., 2012). However, more recently, Chinese investments, in particular via mergers and acquisitions (M\&As) in developed economies, have highlighted the willingness of Chinese firms to tap into competitive assets from the West, such as brands and knowledge (Wu and Ding, 2009; Sun et al., 2012; Rui and Yip, 2008; Amighini et al., 2014). Firms from emerging markets consider FDI to be one of the most effective ways to access and develop strategic assets (Deng, 2009, p. 74; Makino et al., 2002, p. 404). Since the beginning of the 2000s, within the framework of the "go global" strategy, the Chinese government has been encouraging FDI in R\&D activities abroad to help Chinese firms obtain foreign technologies and enhance their technological capabilities (Wu and Ding, 2009, pp. 174-175; Rugman et al., 2014). As highlighted by Huang and Wang (2013, p. 100), this strategy has been driven by a willingness to be more competitive both in international markets and at home. This "double" spectrum of strategic asset-seeking investment abroad has to be taken into account to understand the types and locations of Chinese firms based in foreign countries.

The literature on international business provides many theoretical and empirical studies on the role of FDI as a vehicle to acquire technologies and knowledge capabilities in host countries (Dunning and Lundan, 2008, pp. 551-605). Many scholars have scrutinized emerging markets' MNEs' (EMNEs) strategic asset-seeking investments abroad that are designed to upgrade their technological capabilities (Cui and Jiang, 2009; Zhang and Filippov, 2009; Amighini et al., 2014; De Beule et al., 2014; Huang and Wang, 2013; Nicolas, 2014). However, few studies have examined the results of these strategies in terms of innovation capabilities obtained through strategic asset-seeking investments abroad (Park and Choi, 2014, pp. 104-105). This paper tries to fill this gap by examining the innovation process within Chinese firms and, more precisely, by analyzing the extent to which investments abroad may contribute to enhancing Chinese firms' innovative capabilities. The study comprises four parts. The first part considers the role of strategic-asset seeking investments as a decisive tool to strengthen the innovative capacity of Chinese investors. The second part addresses the major 
investment modes chosen to operate strategic asset investments abroad. The third part links these modes of entry to the internal and external network organization of the firms. The fourth part analyzes the sources of the Chinese firms who have operated FDI in Europe. We use an OECD patent database called "OECD REGPAT July 2013" that compiles patents registered with the European Patent Office (EPO) over the period from 1986 to 2013. We concentrate our analysis on patents registered by Chinese MNEs based in Europe because we assume inter alia that innovations patented by Chinese affiliates in Europe are registered with the EPO. The sample comprises 3,010 patents involving 5,749 citations that we individually scrutinized. We focus our analysis on patents because they reveal the sources, or citations, on which an innovation is based (Cantwell and Mudambi, 2011, p. 209).

\section{Chinese strategic asset-seeking investments abroad}

International strategies aimed at accessing foreign technologies abroad have been studied mainly through the theory of the internationalization of R\&D activities (Dunning and Narula, 1995; Kuemmerle, 1997, 1999; Michel, 2009; Yip and McKern, 2014). Contributions to the internationalization of R\&D activities have been particularly numerous since the beginning of the 1990s (Kogut and Zander, 1993; Birkinshaw, 1996; Kuemmerle, 1997; Mudambi and Navarra, 2004; Cantwell et al., 2004; Criscuolo, 2004; Rao et al., 2012). Most of these contributions have concentrated on developed economies' multinational enterprises (MNEs) because MNEs were largely involved in R\&D internationalization activities. In addition to the "traditional motivations" to invest abroad (market seeking, resource seeking, and efficiency seeking), strategic asset-seeking investments are particularly important for "innovation-driven economy" MNEs, whose main competitive advantages rely on their ability to innovate and continuously create new strategic assets (Dunning and Narula, 1995; Dunning, 1998, p. 50; Gugler et al., 2013, p. 3). Strategic assets may be defined as knowhow, knowledge, experience, capabilities, and resources that contribute to the FSA (Deng, 2009, p. 74).

Recently, the MNEs of emerging markets have embarked on strategic asset-seeking investments abroad, particularly in knowledge-intensive industries (De Beule et al., 2014; Holtbrügge and Kreppel, 2012; Zhang and Roelfsema, 2014). Chinese MNEs have been increasingly involved in strategic asset-seeking FDI since the beginning of the 2000s (Wu and Ding, 2009, p. 175). This phenomenon has been studied from different perspectives based on the "industry-based view" (industry pull and push effects), the "resource-based view" ("asset exploiting" vs "asset seeking”), and the "institution-based view" ("home institutions" vs "host institutions") (see Cui and Jiang, 2010, pp. 753-754; Wang et al., 2012; Gaur et al., 2014; Rugman et al., 2014). The motivations and modes of entry for FDI have been investigated in detail (Buckley et al., 2007; Child and Rodrigues, 2005; Deng, 2007; Alon et al., 2012; Gaffney et al., 2013). Regarding the motivations of Chinese FDI, recent studies have focussed on numerous market-seeking investments, particularly in developed economies and, to a lesser extent, in emerging markets, as well as on resource-seeking investments, particularly in developing countries, such as in Africa (e.g. Alon et al., 2012; Bräutigam and Tang, 2014). Chinese strategic asset investments in developed economies have raised significant interest because they reflect a new dimension of competition in world markets. A recent survey published by the European Chamber of Commerce in China (2013) - analyzed by Nicolas (2014, p. 111) - shows that strategic asset-seeking investments in the European Union are the second most important motivation for Chinese firms to invest in Europe. These new 
IJOEM

10,2

246

developments are of great importance because they challenge the theory of international business and offer new perspectives to apply and complement the main theoretical streams regarding FDI (Dunning et al., 2008; Ghauri and Santangelo, 2012; Huang and Wang, 2011; Contractor, 2013).

Chinese firms' competitiveness in international markets is mainly based on low costs, mature market goods, and standardized technologies (Wang et al., 2012, p. 434; Zhang and Roelfsema, 2014). Chinese firms have gained competitive advantages related to low production costs for relatively "simple" products (Zhang and Roelfsema, 2014, p. 91). Competing in high-value markets first requires the creation of value and thus the offering of specific and differentiated products to customers via innovation (Porter, 2008, p. 40). However, as noted by several studies, Chinese firms' innovation capabilities are rather weak, which is why most Chinese firms do not compete in highly sophisticated industries (Child and Rodrigues, 2005, p. 389; Rugman and Doh, 2008, p. 151). Whereas Chinese FDI in developing and emerging markets is operated due to existing ownership advantages (Li, 2007, p. 299; Shenkar, 2009, p. 150), strategic asset-seeking FDI in developed economies is mainly driven by competitive disadvantages with regard to firms' innovation capabilities (Child and Rodrigues, 2005, pp. 381 and 388; Cheung and Suny, 2009, pp. 314-315; Cui and Jiang, 2009, p. 434).

Studies on Chinese ownership advantages recognize that the main competitive advantages are based less on FSAs and more on country-specific advantages (CSAs), such as the availability of capital, the direct and indirect support from the government linked to their statutes of state-owned enterprises (SOEs) for the majority of Chinese MNEs, and the strengths arising from the large domestic market (Rugman and Li, 2007, p. 337; Zhang and Filippov, 2009, p. 13; Chen and Young, 2010; OECD, 2008a, p. 77; Deng, 2007, p. 78; Wang et al., 2012, p. 434; Child and Rodrigues, 2005, p. 385; Shenkar, 2009, p. 155; Cui and Jiang, 2009, p. 434; Robins, 2013, pp. 532-533; Huang and Wang, 2013, p. 86). Furthermore, similar to other EMNEs, Chinese MNEs face disadvantages created not only by the so-called "liability of foreignness" but also by the fact that their home country is not a developed economy (De Beule et al., 2014; Cui et al., 2014).

Rugman defines an FSA "[...] as a unique capability proprietary to the organization. It may be built upon product or process technology, marketing, or distributional skills" (Rugman and Li, 2007, p. 334). Several types of firm-specific disadvantages have been identified, such as "limited managerial skills" (Shenkar, 2009, p. 158) and weak knowledge capabilities (Zhang and Filippov, 2009, p. 6; Deng, 2007, p. 77; Rugman and Li, 2007, p. 336; Liu and Buck, 2009, p. 179; Child and Rodrigues, 2005, p. 387; Shenkar, 2009, pp. 157-158; OECD, 2008b, p. 290). Weak Chinese FSAs, particularly their poor ability to innovate and generate new knowledge, constitute one of the major drivers of Chinese strategic asset investment abroad (Deng, 2007, p. 78, 2009, p. 74; Makino et al., 2002, p. 404; Cui and Jiang, 2009, p. 434; UNCTAD, 2006, p. 168; Jiang et al., 2007, p. 2; OECD, 2008b, p. 290; Wei et al., 204, p. 364). This situation may explain that most strategic asset FDIs from Chinese MNEs have been directed toward innovative developed countries (overall high domestic technological CSAs) in sectors where local firms benefit from strong technological FSAs (Liu and Woywode, 2013, p. 471; Wu and Ding, 2009, pp. 173-175; Deng, 2009, p. 14; Makino et al., 2002, p. 404; OECD, 2008a, p. 98ss; Wang et al., 2012, p. 433; Amighini and Franco, 2013, p. 154). This approach - examined inter alia through "the awareness-motivation-capability" framework - reflects the aim to catch-up FSAs' deficits through strategic assetseeking investment abroad (Cui et al., 2014, p. 488; Meyer et al., 2009). 
However, Chinese firms benefit from FSAs in such areas as operational flexibility (Hong and Sun, 2006, p. 633; Chang, 2011; Lyles et al, 2014, p. 7). For example, the dynamism and flexibility of so-called "family firms" constitute specific competitiveness assets that benefit Chinese firms (Erdener and Shapiro, 2005, p. 425). Their "networking capabilities" create a competitive advantage fostering Chinese firms' FSAs (Yeung and Liu, 2008, p. 33; Buckley et al., 2007, p. 502; Child and Rodrigues, 2005, p. 386). The networking capabilities of Chinese firms may also encourage them to enter into strategic asset investments with the aim of benefiting from local knowledge due to their ability to create tangible and intangible relationships with domestic firms and institutions in the recipient countries (Boisot and Child, 1996, p. 613ss; Erdener and Shapiro, 2005, p. 421).

\section{Operational modes to upgrade innovative capabilities abroad}

M\&As and, to a lesser extent, Greenfield investments are identified as the main modes of Chinese MNEs' strategic asset FDI (Deng, 2007, p. 14; Sun et al., 2012, p. 4; Rui and Yip, 2008, p. 213; Shenkar, 2009, p. 154; Nicholson and Salaber, 2013, p. 963; Cui and Jiang, 2010, p. 757). Chinese strategic asset-driven M\&A abroad is the dominant strategy to acquire Western partners' brands, human capital, technologies, and intangible assets while using the CSAs of their home country, offering them institutional and financial support to operate their investments (De Beule et al., 2014, p. 137; Rui and Yip, 2008, p. 214; Zhao and Ordonez de Pablos, 2010, p. 156; Child and Rodrigues, 2005, p. 392; Liu and Buck, 2009, p. 171; see also Globerman and Shapiro, 2009, p. 166; OECD, 2008a, pp. 74-75; Jiang et al, 2007, p. 17). Case studies on major Chinese MNEs, such as BOE, Lenovo, and TCL, have scrutinized the main motivations behind these firms to perform M\&As abroad and have confirmed the willingness of Chinese firms to access specific assets abroad to compete with firms from developed countries (Deng, 2007, 2009, pp. 80-88; Liu and Buck., 2009, p. 171; Hong and Sun, 2006, p. 625ss; Li, 2007, p. 304ss; Rui and Yip, 2008, pp. 218-224; Globerman and Shapiro, 2009, p. 166; OECD, 2008a, p. 75).

De Beule et al. (2014, p. 148) show that the choice of the degree of EMNEs ownership abroad does not depend on the technological intensity of the industry. According to a study examining 166 Chinese M\&As abroad from 2004 to 2006, these M\&A operations were "insensitive to industries," suggesting that "[...] M\&A is not considered as the major channel to enhance the firm's capabilities to innovate and to generate new knowledge. Chinese MNEs' goal through M\&A in developed countries may be to catch-up but less likely to outrace their competitors as major innovators" (Jiang et al., 2007, p. 4). Indeed, Chinese M\&As abroad do not succeed in leveraging the innovation capabilities of Chinese firms in most cases thus far (Rugman and Li, 2007, p. 337; Shenkar, 2009, pp. 159-160). According to Rugman and Li, this lack of success may be explained by Chinese firms' lack of experience in R\&D activities, in foreign M\&As, and in "internal managerial" knowledge (Rugman and Li., 2007, p. 336). Furthermore, not all Chinese M\&A operations pursue a strategic asset-seeking strategy (Cui et al., 2014, p. 489). Because Chinese firms lack high-skilled labor and high-tech knowledge, it is difficult for them to upgrade their innovation capabilities through M\&As in foreign countries (Shenkar, 2009, pp. 159-160). At this stage, the effects of M\&As on Chinese investors are largely understood as the benefits to exploit the existing knowledge held by Western partners without any technological upgrading (Deng, 2009, p. 83).

M\&As are not the sole strategy used to acquire knowledge capabilities in developed economies (De Beule et al., 2014). Greenfield subsidiaries may develop interactions with local firms and institutions in the recipient country. Some interactions may be based on the transfer of codified knowledge, whereas other links relate to exchanges of tacit 
IJOEM

10,2

248

knowledge. Several studies have also demonstrated the importance of exchanges of tacit knowledge in the innovation process of co-located firms (Maskell and Malmberg, 1999, p. 172; Asheim and Gertler, 2005, p. 292; Dunning and Lundan, 2008, p. 371). According to Tao et al, the potential for network links with local firms and institutions influences entry decisions and modes of entry in a foreign market (Tao et al., 2013, p. 108).

Some studies have highlighted the role of agglomeration effects with local firms, particularly when the MNEs' affiliates are located within innovative clusters (Jaffe et al., 1993; Audretsch and Feldman, 1996, 2000; Iammarino and McCann, 2006; Tinguely, 2013; Gugler et al., 2013; Kohlbacher et al., 2013; Perri and Andersson, 2014). In this context, the particular role of clusters as important drivers of innovation output based on foreign firms' interactions with members of local clusters has been highlighted by several studies demonstrating the potential fruitful results of MNEs' FSAs with local firms' FSAs, host CSAs, or host region-specific advantages (Birkinshaw and Sölvell, 2000; Tavares Lehmann and Teixeira, 2006; Mudambi and Swift, 2010, Cantwell and Mudambi, 2011; Tinguely 2013). Several studies have described the potential conflicts between the "knowledge creation" objectives of MNEs' affiliates in host countries and "knowledge protection" concerns, or in other words, the willingness of investors abroad to protect their knowledge from undue appropriation by host countries' counterparts (Arikan, 2009, p. 672; Perri and Andersson, 2014, pp. 64-65). This latter concern does not seem to play an important role in Chinese FDI at this stage due to, inter alia, Chinese firms' lack of strong innovative knowhow.

Although most examples are based on MNEs from developed countries (Tinguely, 2013; Gugler et al., 2013), we suggest that Chinese firms are also attracted by externalities created within clusters and innovative regions. For example, a study on Chinese FDI in the automobile sector in 44 foreign countries shows that the Chinese investors were attracted by the "potential spillover" from clusters (Amighini and Franco, 2013, p. 160). Clusters reduced institutional distances and therefore endogenous and exogenous uncertainty, which may attract Chinese firms (De Beule et al., 2014; Yildiz, 2014). Chinese firms are also attracted by the quality of the labor market, whose efficiency is usually better within clusters (Amighini and Franco, 2013). Because knowledge is partially tacit, the role of exchanges within local innovation systems is particularly important for fostering innovation (Cantwell and Mudambi, 2011, p. 209). In this respect, some Chinese MNEs, such as Huawei Technologies, Haier, and ZTE Corporation, have established R\&D affiliates within the clusters and innovation centers of host countries (Cui and Jiang, 2009, p. 437; Buckley et al., 2008, pp. 738-739; Poncet, 2007, p. 12). Contractor's study on EMNEs finds a higher propensity of EMNEs to enter into collaboration agreements with host country counterparts due to their cultural and institutional ability to network (Contractor, 2013, p. 313). As indicated above, Chinese firms benefit from FSAs in terms of networking capabilities (Boisot and Child, 1996, p. 623). Therefore, these firms may obtain advantages by locating within innovative regions and prospecting for strategic interactions with local firms and institutions. According to Mathews, investments oriented toward clusters and innovative centers may be explained using the "linkage-leverage-learning" (LLL) model, which states that latecomer firms attempt to obtain competitive advantages through LLL strategies in host countries (Mathews, 2006, pp. 18-20; Li, 2007, p. 299).

\section{Strategic portfolio of Chinese activities abroad}

Strategic asset-seeking FDIs are based on a firm's strategy to enhance its knowledgebased competitiveness through optimal interactions between its competitive assets and 
the location advantages offered by the host country (Buckley and Casson, 1976; Rugman and Verbeke, 1992, p. 762; Dunning and Lundan, 2008, pp. 72-74; Rugman, 2010, p. 4). Considering the firm as a unit of analysis, the Rugman's matrix based on FSAs and CSAs offers a powerful framework for studies dedicated to strategic assetseeking investment (see Rugman, 1981). Furthermore, according to this matrix, we may analyze the internal organizational structures and interfirm linkages of specific firms (Collinson and Rugman, 2011, p. 32). MNEs constitute a spectrum of networks that are internal and external to the firm (Rugman and Verbeke, 2001; Noorderhaven and Harzing, 2009; Giroud and Scott-Kennel, 2009; Hallin et al., 2011; Collinson and Wang, 2012; Santangelo, 2012; Verbeke, 2009; Meyer et al., 2011; Rugman et al., 2011). The "competence-creating" activities of MNEs' affiliates are associated with the MNEs' embeddedness in their local networks (Cantwell and Mudambi, 2011, p. 207). MNEs' subsidiary FSAs are linked to the FSAs of local firms collocated within clusters or local innovation systems (Narula, 2013, p. 12).

Recent studies have demonstrated that MNEs' strategic asset investments in specific locations are part of the strategic management of a "knowledge-cluster portfolio" with the aim of enhancing the innovative firm's FSAs (Rugman and Verbeke, 2001, p. 240; Tinguely, 2013; Gugler et al., 2013; Mudambi, 2008, p. 699; Meyer et al., 2011, p. 236). Mudambi notes that "firms can enhance their competitive advantage by dispersing their creative endeavours, tapping into multiple centres of excellence and coordinating knowledge across geographic space” (2008, p. 700). This mechanism combines the external embeddedness of the firm with its internal embeddedness. Internal embeddedness relies on the internal organization of the firm. The types of links among subsidiaries and between the subsidiaries and their headquarters are particularly important for "knowledge transfers," "knowledge-absorptive capacities," and the "knowledge generation" of the firms (Gugler et al., 2013, p. 8; Segarra-Cipres et al., 2014).

As highlighted by recent works on the relationships between subsidiaries and their headquarters, a firm's entities do not necessarily share their experience and knowledge with the other parts of the firm (Narula, 2013; Mudambi et al., 2014; Mudambi, 2011; Najafi-Tavani et al., 2014). As noted by Narula (2013, p. 2), the literature considers two main scenarios regarding the "subsidiary-parent firm" relationship: the traditional "hierarchical" relationship and the "federal" structure (see also, Foss et al., 2012; Park and Choi, 2014). The Chinese model relies more on the "hierarchical" model than the "federal" model. The process occurs within a strong "internal embeddedness" structure due to the robust hierarchical structure of most Chinese firms (for a general discussion regarding the internal embeddedness and external embeddedness of MNEs, see Narula, 2013, p. 8ss). This model may facilitate the institutional transfer of information inside the firm; however, as suggested above, the efficiency of these transfers may be called into question due to the weaknesses of most internal entities with regard to their technological FSAs. Furthermore, as suggested in the previous section, contrary to what has been observed in the case of developed countries' MNEs, such as in the case of Swiss pharmaceutical companies (Tinguely, 2013), it is unlikely that Chinese MNEs benefit from a successful internal management of affiliate networks in terms of exchanging and generating new knowledge developed in different subsidiaries located in different countries (Shenkar, 2009, p. 150). Nevertheless, we suggest that external relationships with local counterparts in developed host countries help Chinese MNEs to generate innovations within individual subsidiaries located abroad. The process is uncertain, and potential positive externalities may take time to be achieved 
IJOEM

10,2

(Tao et al., 2013, pp. 114-115). However, whereas developed economies' firms may be more reluctant to take risks and engage in long-term results strategies, we may assume that Chinese firms - at least those that have strong links with the government (e.g. SOEs) - may have less concern in this respect and may be more inclined to engage in "network" FDI abroad.

\section{Synthesis and propositions based on a patent analysis}

According to the previously described theoretical and empirical thoughts based on the economic literature, our study examines the following propositions regarding the innovation capabilities of Chinese MNEs and particularly the role of FDI in strengthening their ability to generate knowledge:

(1) Collaborations with foreign firms to upgrade their innovation capabilities are limited. The number of co-owned patents is low.

(2) The ability of Chinese MNEs to generate innovation based on their own knowledge is low. The patents held by Chinese MNEs that incorporate the knowledge gained from previous patents are largely based on patents developed by other applicants (i.e. the self-citation rate is low).

(3) The patents held by Chinese MNEs that incorporate the knowledge gained from previous patents registered by other applicants are largely based on foreign patents (i.e. the citation rate of patents registered by other Chinese firms is low). Foreign patents cited in Chinese MNEs' patents are largely registered by firms located in developed economies.

(4) M\&As have a moderate impact on the ability of Chinese MNEs to generate new knowledge based on the acquired or merged foreign firms.

(5) Network effects contribute to generating new knowledge within the Chinese affiliates located in clusters or innovative centers. Linkages with independent domestic firms and institutions located in the recipient country - particularly within clusters - are significant drivers for generating innovations based on foreign knowledge.

\section{Methodology and data \\ Methodology}

As noted by the OECD (2009, pp. 12-13), patents are frequently used as "indicators of invention and give information on the output and process of inventive activities." Furthermore, "they provide a detailed description of how the inventions have been made and the prior art" (OECD, 2009, p. 30). These properties are interesting for the analysis and assessment of knowledge transfers. However, patents suffer from drawbacks that must be taken into account in the interpretation of the patent analysis results. As highlighted by the $\mathrm{OECD}(2009$, p. 13), companies operating in different industries and countries can behave differently in the patent process. Strategically, some companies may prefer not to patent their inventions and to transfer knowledge tacitly.

The counting method to determine the number of patents filed by an applicant is fractional, meaning that a patent is weighted by its applicants' shares. In other words, fractional counts allow a number of applicants to share a patent and avoid double counting (OECD, 2009, p. 64). For example, if the same patent is developed and filed jointly by two firms, each firm will get 0.5 share of the patent. A patent filed by multiple 
applicants represents a cooperation/collaboration between the applicants to develop the patented invention (OECD, 2009, p. 64). This "co-ownership of patents" indicates that the involved applicants have shared knowledge and other resources (Avidity IP Ltd, 2012, p. 1). Suggesting that Chinese MNEs are strategic - asset seeking, an analysis of the co-ownership of patents, more specifically the localization of the co-applicants, can provide insight into the level of knowledge transfer through collaboration.

Alternatively, patent citations provide information on the knowledge diffusion across firms, industries, and regions or countries (OECD, 2009, p. 31). Thus, we can track the diffusion of knowledge and identify the influence of specific inventions (patents) on new inventions (patents). Such tracking can be accomplished based on "patent citations": "the use of previous inventions (patents) in new inventions" (OECD, 2009, p. 30). However, patent citations must also be considered with caution because they may provide a "noisy signal" of knowledge flows (Jaffe et al., 1998). Even if the applicant mentions the prior patents on which his patent is based, the patent examiner may include other patent citations. This situation can result in potential knowledgeflow biases because the applicant may not be aware of some contents of the patent citations (Criscuolo and Verspagen, 2008).

The citation indicators provide information regarding the cited firm (i.e. the applicant for the patent on which a Chinese patent is based): name, localization, operating sector, and link with the citing firm (e.g. operations in the same country, same region, same cluster, or linked through an M\&A). It is worthwhile to distinguish self-citations and citations of patents from other firms. As noted by the OECD (2009, p. 113), "citations to patents that belong to the same applicant (self-citations) mostly represent internalized transfers of knowledge, whereas citations to other patents are closer to diffused spillovers." Self-citations allow us to evaluate the ability of firms to innovate, whereas citations of patents from other firms allow us to assess the importance of knowledge spillovers.

Using a descriptive statistical method of patents and patent citations, we assess the significance of knowledge spillovers for some Chinese MNEs in their European investments.

\section{Data sample}

Our sample is based on patents registered by Chinese MNEs with the EPO over the period from 1986 to 2013. Because our objective is to understand whether Chinese MNEs invest in Europe to benefit from knowledge transfers, we consider Chinese MNEs listed on the Shanghai Stock Exchange that have undertaken investments in European countries. Among these Chinese MNEs, 24 firms are identified as applicants (i.e. firms that have registered a patent with the EPO) in the OECD patent database called "OECD REGPAT July 2013," which lists all of the patents filed with the EPO. These firms registered 3,010 patents with the EPO over the period considered and cited 5,749 other patents on which their own patents are based (see Table I).

Table I presents the 24 Chinese firms considered in our sample. For each firm, the table indicates its industrial sector (two-digit SIC code), the number of patents registered, the number of citations included in the patents registered, and the percentage of citations of the entire sample. The citation indications are based on the EPO web site (www.epo.org/searching/free/espacenet.html), which provides a list of the patents published worldwide with related information, including their citations.

The sample comprises the four Chinese firms listed in the ranking of the 50 most innovative companies in 2010 (Bloomberg, 2010): BYD (8), Haier (27), Lenovo (29), and 
IJOEM

10,2

252
Table I.

Firms included in the total sample, number of filed patents at EPO and citations

\begin{tabular}{|c|c|c|c|c|}
\hline Company name & Sector (SIC-2 digits) & $\begin{array}{c}\text { Number of } \\
\text { patents }\end{array}$ & $\begin{array}{l}\text { Number of } \\
\text { citations }\end{array}$ & $\begin{array}{l}\% \text { of total } \\
\text { citations }\end{array}$ \\
\hline $\begin{array}{l}\text { Angang Steel Company } \\
\text { Ltd }\end{array}$ & Primary metal industry & 2 & 7 & 0.12 \\
\hline $\begin{array}{l}\text { Baosteel Group } \\
\text { Corporation }\end{array}$ & Primary metal industry & 11 & 6 & 0.10 \\
\hline Blue Star Silicone & Chemicals and allied products & 3 & 16 & 0.28 \\
\hline Byd Company & $\begin{array}{l}\text { Electronic and other electrical } \\
\text { components }\end{array}$ & 85.5 & 456 & 7.93 \\
\hline $\begin{array}{l}\text { China International Marine } \\
\text { Containers Group }\end{array}$ & Fabricated metal products & 13.5 & 40 & 0.70 \\
\hline $\begin{array}{l}\text { China Mobile } \\
\text { Communications } \\
\text { Corporation }\end{array}$ & Communications & 20 & 24 & 0.42 \\
\hline CITIC Group & $\begin{array}{l}\text { Depositary institutions and } \\
\text { real estates }\end{array}$ & 6.5 & 10 & 0.17 \\
\hline Chongqing Lifan Industry & Transportation equipment & 1 & 5 & 0.09 \\
\hline Founder Electronics & Business services & 1 & 1 & 0.02 \\
\hline Gree Electric Appliance & $\begin{array}{l}\text { Electronic and other electrical } \\
\text { components }\end{array}$ & 5 & 9 & 0.16 \\
\hline $\begin{array}{l}\text { Guangzhou SAT Infrared } \\
\text { Technology (SATIR) }\end{array}$ & $\begin{array}{l}\text { Electronic and other electrical } \\
\text { components }\end{array}$ & 3 & 14 & 0.24 \\
\hline Haier Group & $\begin{array}{l}\text { Electronic and other electrical } \\
\text { components }\end{array}$ & 3.5 & 8 & 0.14 \\
\hline Hisense & Miscellaneous repair services & 2 & 3 & 0.05 \\
\hline Huaqi & Miscellaneous repair services & 1 & 1 & 0.02 \\
\hline $\begin{array}{l}\text { Huawei Technologies } \\
\text { Co. Ltd }\end{array}$ & Business services & 2,076 & 4,450 & 77.40 \\
\hline Lenovo Group Ltd & $\begin{array}{l}\text { Industrial and commercial } \\
\text { machinery and computer } \\
\text { equipment }\end{array}$ & 26.5 & 60 & 1.04 \\
\hline Petrochina & Oil and gas extraction & 7 & 14 & 0.24 \\
\hline Sany & $\begin{array}{l}\text { Automotive repair, services } \\
\text { and parking }\end{array}$ & 6 & 19 & 0.33 \\
\hline Sinochem International & $\begin{array}{l}\text { Wholesale trade - nondurable } \\
\text { goods }\end{array}$ & 1 & 3 & 0.05 \\
\hline Sinopec & Oil and gas extraction & 105 & 341 & 5.93 \\
\hline Suntech Power Holdings & $\begin{array}{l}\text { Electronic and other electrical } \\
\text { components }\end{array}$ & 1 & 2 & 0.03 \\
\hline TCL - Alcatel/Thomson & Motion pictures & 28 & 86 & 1.50 \\
\hline Wuhan Guide Infrared & $\begin{array}{l}\text { Electronic and other electrical } \\
\text { components }\end{array}$ & 2 & 4 & 0.07 \\
\hline ZTE & Business services & 600 & 170 & 2.96 \\
\hline Total & & $3,010.5$ & 5,749 & 100 \\
\hline
\end{tabular}

China Mobile Communications Corporation (44). However, the number of patents registered with the EPO by these four companies is relatively small. These companies do not systematically register all of their discoveries with the EPO. Of the Chinese firms considered here, Huawei has registered the largest number of patents with the EPO (approximately 80 percent of the patents identified in our sample). As a result, Huawei also registers the largest number of citations (approximately 77 percent). Therefore, we must interpret our results with caution due to this potential bias. 


\section{Results}

1. The number of co-owned patents (or co-patents) is low, suggesting a low level of knowledge transfer through collaboration

Table II reports a low number of co-patents. Only 47 patents were filed by more than one applicant and therefore have an applicant share between 0 and 1 . The localization of the co-applicants indicates that Chinese firms primarily cooperate with other Chinese firms (76.6 percent). Collaborations with European firms represent 12.8 percent, whereas collaborations with US firms account for 6.4 percent of co-applicants.

\section{The ability of Chinese MNEs to generate innovation based on their own knowledge} is low. The patents held by Chinese MNEs that incorporate the knowledge contained in previous patents are largely based on patents developed by other applicants (i.e. the self-citation rate is low)

Table III illustrates the small percentage of self-citations identified in the database. On average, only 3.8 percent of our total sample of citations is self-citations, whereas 4.5 percent of the sample is self-citations when Huawei's citations are excluded. This result suggests that Chinese firms develop their own technology mainly through the incorporation of the knowledge held by other firms rather than on their own knowledge, which appears to be limited. A study by Jaffe and Trajtenberg (1999) reports the fraction of citations that are self-citations for different countries. In 1993, the average fraction of self-citations in the USA was approximately 30 percent, whereas this fraction was approximately 20 percent in Great Britain, France, Germany, and Japan. Sampat (2005) finds a self-citation rate of 11 percent for the USA for the 2001-2003 period.

Self-citations have been excluded in the subsequent patent analyses given that the aim of this study is to track knowledge transfers sourced from third parties.

3. The patents held by Chinese MNEs that incorporate the knowledge contained in previous patents registered by other applicants are largely based on foreign patents (i.e. the citation rate of patents registered by other Chinese firms is low). Foreign patents cited in Chinese MNEs' patents are largely registered by firms located in developed economies Our results demonstrate that Chinese patents are largely based on patents held by firms in industrialized countries.

\begin{tabular}{|c|c|c|c|}
\hline Country of co-applicants & Number of co-patents & Share of co-patents by country (\%) & \\
\hline $\mathrm{AU}$ & 1 & 2.1 & \\
\hline $\mathrm{CN}$ & 36 & 76.6 & \\
\hline $\mathrm{DE}$ & 2 & 4.3 & \\
\hline FR & 1 & 2.1 & \\
\hline HK & 1 & 2.1 & \\
\hline $\mathrm{SE}$ & 1 & 2.1 & \\
\hline $\mathrm{SE} / \mathrm{JP} / \mathrm{FR} / \mathrm{DE}$ & 2 & 4.3 & \\
\hline US & 3 & 6.4 & \\
\hline Total & 47 & 100.0 & \\
\hline \multicolumn{3}{|c|}{$\begin{array}{l}\text { Notes: AU, Australia; CN, China; DE, Germany; FR, France; HK, Hong Kong; SE, Sweden; JP, Japan; } \\
\text { US, USA } \\
\text { Source: Own calculations based on OECD REGPAT July } 2013\end{array}$} & $\begin{array}{r}\text { Table II. } \\
\text { Localization of } \\
\text { co-patents }\end{array}$ \\
\hline
\end{tabular}


IJOEM 10,2

254
Company name

Total sample

Angang Steel Company Ltd

Baosteel Group Corporation

Blue Star Silicone

Byd Company

China International Marine Containers Group

China Mobile Communications Corporation

CITIC Group

Chongqing Lifan Industry

Founder Electronics

Gree Electric Appliance

Guangzhou SAT Infrared Technology (SATIR)

Haier Group

Hisense

Huaqi

Huawei Technologies Co. Ltd

Lenovo Group Ltd

Petrochina

Sany

Sinochem International

Sinopec

Suntech Power Holdings

TCL - Alcatel/Thomson

Wuhan Guide Infrared

Table III.

Self-citations
ZTE

Total
No. of citations No. of self-citations \% self-citations

$\begin{array}{rrr}7 & 0 & 0.0 \\ 6 & 1 & 16.7 \\ 16 & 0 & 0.0 \\ 456 & 4 & 0.9 \\ 40 & 3 & 7.5 \\ 24 & 0 & 0.0 \\ 10 & 0 & 0.0 \\ 5 & 0 & 0.0 \\ 1 & 0 & 0.0 \\ 9 & 0 & 0.0 \\ 14 & 0 & 0.0 \\ 8 & 0 & 0.0 \\ 3 & 0 & 0.0 \\ 1 & 0 & 0.0 \\ 4,450 & 163 & 3.7 \\ 60 & 0 & 0.0 \\ 14 & 0 & 0.0 \\ 19 & 0 & 0.0 \\ 3 & 0 & 0.0 \\ 341 & 46 & 13.5 \\ 2 & 0 & 0.0 \\ 86 & 0 & 0.0 \\ 4 & 0 & 0.0 \\ 170 & 4 & 2.4 \\ 5,749 & 221 & 3.8\end{array}$

Table IV presents the citations incorporated in the Chinese patents of our sample (excluding self-citations and citations with insufficient information). Only 2.8 percent of the citations are based on previous patents registered by other Chinese firms. Furthermore, Chinese firms mainly cite patents from the USA (46 percent), Western Europe (25 percent), Japan (15 percent), and Canada (4 percent), and 95 percent of citations originate in the OECD countries. Excluding the citations of other Chinese firms, 98 percent of citations originate in the OECD countries (Table V).

However, as previously mentioned, Huawei biases the results due to its relatively important role in patenting and citing. When excluding Huawei, the remaining firms mainly cite patents from the USA (38 percent), Japan (27 percent), and Western Europe (19 percent) (Table IV). Approximately 91 percent of citations originate in the OECD countries. Excluding the citations of other Chinese firms, 98 percent of citations originate in the OECD countries (Table V).

\section{M\&As have a moderate impact on the ability of Chinese MNEs to generate new knowledge based on the acquired or merged foreign firms}

Table VI demonstrates that 39.2 percent of the citations of Chinese MNEs are related to local firms located in their recipient country. The percentage of citations involving a local firm within the recipient country is at least 50 percent for nine of 24 firms. When excluding Huawei (Table VI), only 18.4 percent of the citations of Chinese MNEs are related to local firms in the recipient country. This information does not indicate that 


\begin{tabular}{|c|c|c|c|}
\hline Country & No. of citations & $\%$ citations & Chinese \\
\hline \multicolumn{3}{|c|}{ (a) Total sample } & \multirow{4}{*}{$\begin{array}{l}\text { innovative } \\
\text { capabilities }\end{array}$} \\
\hline US & 2,517 & 45.74 & \\
\hline $\mathrm{JP}$ & 789 & 14.34 & \\
\hline FI & 364 & 6.61 & \\
\hline KR & 266 & 4.83 & \\
\hline $\mathrm{SE}$ & 259 & 4.71 & \\
\hline DE & 246 & $\begin{array}{l}4.71 \\
4.47\end{array}$ & 255 \\
\hline FR & 243 & \multicolumn{2}{|l|}{4.42} \\
\hline CA & 225 & \multicolumn{2}{|l|}{4.09} \\
\hline $\mathrm{CN}$ & 156 & \multicolumn{2}{|l|}{2.83} \\
\hline GB & 142 & \multicolumn{2}{|l|}{2.58} \\
\hline NL & 65 & \multicolumn{2}{|l|}{1.18} \\
\hline IL & 47 & \multicolumn{2}{|l|}{0.85} \\
\hline IT & 37 & \multicolumn{2}{|l|}{0.67} \\
\hline TW & 37 & \multicolumn{2}{|l|}{0.67} \\
\hline $\mathrm{CH}$ & 19 & \multicolumn{2}{|l|}{0.35} \\
\hline $\mathrm{AU}$ & 11 & \multicolumn{2}{|l|}{0.20} \\
\hline IE & 10 & \multicolumn{2}{|l|}{0.18} \\
\hline $\mathrm{BE}$ & 8 & \multicolumn{2}{|l|}{0.15} \\
\hline DK & 7 & \multicolumn{2}{|l|}{0.13} \\
\hline $\mathrm{ES}$ & 7 & \multicolumn{2}{|l|}{0.13} \\
\hline SG & 7 & 0.13 & \\
\hline NO & 6 & 0.11 & \\
\hline SU & 6 & 0.11 & \\
\hline UD & 5 & 0.09 & \\
\hline AT & 2 & 0.04 & \\
\hline BB & 2 & 0.04 & \\
\hline BM & 2 & 0.04 & \\
\hline $\mathrm{HK}$ & 2 & 0.04 & \\
\hline IN & 2 & 0.04 & \\
\hline KY & 2 & 0.04 & \\
\hline PL & 2 & 0.04 & \\
\hline RU & 2 & 0.04 & \\
\hline Others & 8 & 0.16 & \\
\hline Total & 5,503 & 100.00 & \\
\hline (b) Firms & & & \\
\hline US & 474 & 38.44 & \\
\hline $\mathrm{JP}$ & 332 & 26.93 & \\
\hline $\mathrm{CN}$ & 85 & 6.89 & \\
\hline $\mathrm{DE}$ & 69 & 5.60 & \\
\hline FR & 48 & 3.89 & \\
\hline $\mathrm{KR}$ & 48 & 3.89 & \\
\hline $\mathrm{FI}$ & 38 & 3.08 & \\
\hline GB & 30 & 2.43 & \\
\hline CA & 24 & 1.95 & \\
\hline $\mathrm{SE}$ & 20 & 1.62 & \\
\hline NL & 14 & 1.14 & \\
\hline TW & 13 & 1.05 & \\
\hline IT & 11 & 0.89 & \\
\hline $\mathrm{CH}$ & 6 & 0.49 & Table IV. \\
\hline & & & Localization \\
\hline & & (continued) & of citations \\
\hline
\end{tabular}




\begin{tabular}{llcr}
\hline IJOEM & Country & No. of citations & \% citations \\
\cline { 2 - 4 } 10,2 & SU & 6 & 0.49 \\
& BE & 3 & 0.24 \\
& ES & 2 & 0.16 \\
IL & 2 & 0.16 \\
$\mathbf{2 5 6}$ & RU & 2 & 0.16 \\
& AT & 1 & 0.08 \\
AU & 1 & 0.08 \\
& BR & 1 & 0.08 \\
& HK & 1 & 0.08 \\
& IN & 1 & 0.08 \\
& ZA & 1 & 0.08
\end{tabular}

Notes: US, USA;JP, Japan; FI, Finland; SE, Sweden; KR, Korea; DE, Germany; FR, France; CA, Canada; CN, China; GB, UK; NL, the Netherlands; IL, Israel; IT, Italy; CH, Switzerland; TW, Taiwan; IE, Ireland; AU, Australia; BE, Belgium; DK, Denmark; SG, Singapore; SU, Soviet Union; NO, Norway; ES, Spain; KY, Cayman Islands; BB, Barbados; BM, Bermuda; BR, Brazil; BS, Bahamas; HK, Hong Kong; IN, India; KHK, Cambodia; PL, Poland; ZA, South Africa. The total number of citations does not include selfcitations and citations with a lack of information

Table IV. $\quad$ Source: Own calculations based on OECD REGPAT July 2013

Localization of citations

\begin{tabular}{lcccc}
\hline & \multicolumn{2}{c}{ With Chinese citations } & \multicolumn{2}{c}{ Without Chinese citations } \\
Country & No. of citations & \% citations & No. of citations & \% citations \\
\hline (a) Total sample & & & & \\
OECD countries & 5,225 & 94.95 & 5,225 & 97.72 \\
Non-OECD countries & 278 & 5.05 & 122 & 2.28 \\
Total & 5,503 & 100 & 5,347 & 100 \\
(b) Firms without Huawei & & & & \\
OECD countries & 1,121 & 90.91 & 1,121 & 97.65 \\
Non-OECD countries & 112 & 9.09 & 27 & 2.35 \\
Total & 1,233 & 100 & 1,148 & 100
\end{tabular}

Source: Own calculations based on OECD REGPAT July 2013

there is a direct link between FDI and the citation of a domestic firm's patent. It is difficult to obtain accurate information on this issue. However, we may assume that a significant part of the citations are linked to the fact that the Chinese firm is located in the recipient country.

Table VI (last column) indicates that Chinese MNEs and the local firms cited are active within the same industry for approximately 89 percent of the citations. This "sectoral relatedness" (Salter and Weinhold, 1979) is not surprising, particularly in the case of strategic asset seekers (Onal, 2009, p. 5). A similar percentage of sectoral relatedness is observed for the sample without Huawei (Table V - last column).

Our analysis distinguishes between the citations of local firms that are part of a M\&A and the citations of local firms that are not part of a M\&A. As reported above, 39.2 percent of the citations of Chinese MNEs are related to local firms located in their recipient country. This 39.2 percent of "local citations" are categorized as follows: 1.04 percent involve local firms that are part of a M\&A, and 38.16 percent involve local 


\begin{tabular}{|c|c|c|c|c|c|c|}
\hline Company name & $\begin{array}{l}\text { No. of } \\
\text { citations } \\
(1)\end{array}$ & $\begin{array}{l}\text { No. of citations } \\
\text { mentioning a } \\
\text { domestic firm } \\
\text { within the host } \\
\text { country (2) }\end{array}$ & $\begin{array}{l}\% \text { citations } \\
\text { mentioning a } \\
\text { domestic firm } \\
\text { within the host } \\
\text { country (3) }\end{array}$ & $\begin{array}{l}\text { No. of cited } \\
\text { firms' sector } \\
\text { related to } \\
\text { citing firm's } \\
\text { one (4) }\end{array}$ & $\begin{array}{l}\% \text { cited } \\
\text { firms' sector } \\
\text { related to } \\
\text { citing firm's } \\
\text { one (5) } \\
\end{array}$ & $\begin{array}{r}\text { Chinese } \\
\text { MNEs' } \\
\text { innovative } \\
\text { capabilities }\end{array}$ \\
\hline \multicolumn{7}{|l|}{ (a) Total sample } \\
\hline $\begin{array}{l}\text { Ltd } \\
\text { Baosteel Group }\end{array}$ & 7 & 3 & 42.86 & 7 & 100.00 & \\
\hline Corporation & 5 & 0 & 0.00 & 4 & 80.00 & \\
\hline Blue Star Silicone & 16 & 6 & 37.50 & 15 & 93.75 & \\
\hline Byd Company & 448 & 21 & 4.69 & 398 & 88.84 & \\
\hline $\begin{array}{l}\text { China International } \\
\text { Marine Containers }\end{array}$ & & & & & & \\
\hline $\begin{array}{l}\text { Group } \\
\text { China Mobile }\end{array}$ & 37 & 1 & 2.70 & 24 & 64.86 & \\
\hline Communications & & & & & & \\
\hline Corporation & 24 & 10 & 41.67 & 22 & 91.67 & \\
\hline $\begin{array}{l}\text { CITIC Group } \\
\text { Chongqing Lifan }\end{array}$ & 10 & 0 & 0.00 & 8 & 80.00 & \\
\hline Industry & 5 & 0 & 0.00 & 5 & 100.00 & \\
\hline Founder Electronics & 1 & 0 & 0.00 & 0 & 0.00 & \\
\hline $\begin{array}{l}\text { Gree Electric Appliance } \\
\text { Guangzhou SAT }\end{array}$ & 9 & 5 & 55.56 & 7 & 77.78 & \\
\hline $\begin{array}{l}\text { Infrared Technology } \\
\text { (SATIR) }\end{array}$ & 14 & 10 & 71.43 & 14 & 100.00 & \\
\hline Haier Group & 8 & 6 & 75.00 & $\begin{array}{r}1+4 \\
6\end{array}$ & 75.00 & \\
\hline Hisense & 3 & 2 & 66.67 & 3 & 100.00 & \\
\hline Huaqi & 1 & 1 & 100.00 & 1 & 100.00 & \\
\hline $\begin{array}{l}\text { Huawei Technologies } \\
\text { Co. Ltd }\end{array}$ & 4,270 & 1,930 & 45.20 & 3,830 & 8970 & \\
\hline Lenovo Group Ltd & 60 & 30 & 50.00 & $\begin{array}{r}5,050 \\
52\end{array}$ & $\begin{array}{l}0.10 \\
86.67\end{array}$ & \\
\hline Petrochina & 14 & 5 & 35.71 & 13 & 92.86 & \\
\hline Sany & 19 & 10 & 52.63 & 19 & 100.00 & \\
\hline Sinochem International & 3 & 2 & 66.67 & 3 & 100.00 & \\
\hline Holdings & 2 & 0 & 0.00 & 2 & 100.00 & \\
\hline TCL - Alcatel/Thomson & 86 & 21 & 24.42 & 63 & 73.26 & \\
\hline Wuhan Guide Infrared & 4 & 0 & 0.00 & 4 & 100.00 & \\
\hline ZTE & 166 & 94 & 56.63 & 156 & 93.98 & \\
\hline Total & 5,503 & 2,157 & 39.20 & $4,931.00$ & 89.61 & \\
\hline $\begin{array}{l}\text { (b) Firms without Huawei } \\
\text { Angang Steel }\end{array}$ & & & & & & \\
\hline $\begin{array}{l}\text { Company Ltd } \\
\text { Baosteel Group }\end{array}$ & 7 & 3 & 42.86 & 7 & 100.00 & \\
\hline Corporation & 5 & 0 & 0.00 & 4 & 80.00 & \\
\hline Blue Star Silicone & 16 & 6 & 37.50 & 15 & 93.75 & Table VI. \\
\hline Byd Company & 448 & 21 & 4.67 & 398 & $\begin{array}{c}88.44 \\
\text { (continued) }\end{array}$ & $\begin{array}{r}\text { Domestic citations } \\
\text { within the host } \\
\text { country and sectoral } \\
\text { relatedness }\end{array}$ \\
\hline
\end{tabular}


IJOEM

10,2

\begin{tabular}{|c|c|c|c|c|c|}
\hline Company name & $\begin{array}{c}\text { No. of } \\
\text { citations } \\
\text { (1) }\end{array}$ & $\begin{array}{l}\text { No. of citations } \\
\text { mentioning a } \\
\text { domestic firm } \\
\text { within the host } \\
\text { country (2) }\end{array}$ & $\begin{array}{l}\% \text { citations } \\
\text { mentioning a } \\
\text { domestic firm } \\
\text { within the host } \\
\text { country (3) }\end{array}$ & $\begin{array}{l}\text { No. of cited } \\
\text { firms' sector } \\
\text { related to } \\
\text { citing firm's } \\
\text { one (4) }\end{array}$ & $\begin{array}{l}\% \text { cited } \\
\text { firms' sector } \\
\text { related to } \\
\text { citing firm's } \\
\text { one (5) }\end{array}$ \\
\hline \multicolumn{6}{|l|}{ China International } \\
\hline $\begin{array}{l}\text { Group } \\
\text { China Mobile }\end{array}$ & 37 & 1 & 2.70 & 24 & 64.86 \\
\hline Communications & & & & & \\
\hline Corporation & 24 & 10 & 41.67 & 22 & 91.67 \\
\hline $\begin{array}{l}\text { CITIC Group } \\
\text { Chongqing Lifan }\end{array}$ & 10 & 0 & 0.00 & 8 & 80.00 \\
\hline Industry & 5 & 0 & 0.00 & 5 & 100.00 \\
\hline Founder Electronics & 1 & 0 & 0.00 & 0 & 0.00 \\
\hline $\begin{array}{l}\text { Gree Electric Appliance } \\
\text { Guangzhou SAT }\end{array}$ & 9 & 5 & 55.56 & 7 & 77.78 \\
\hline Infrared Technology & & & & & \\
\hline (SATIR) & 14 & 10 & 71.43 & 14 & 100.00 \\
\hline Haier Group & 8 & 6 & 75.00 & 6 & 75.00 \\
\hline Hisense & 3 & 2 & 66.67 & 3 & 100.00 \\
\hline Huaqi & 1 & 1 & 100.00 & 1 & 100.00 \\
\hline Lenovo Group Ltd & 60 & 30 & 50.00 & 52 & 86.67 \\
\hline Petrochina & 14 & 5 & 38.46 & 13 & 100.00 \\
\hline Sany & 19 & 10 & 52.63 & 19 & 100.00 \\
\hline Sinochem International & 3 & 2 & 66.67 & 3 & 100.00 \\
\hline Sinopec & 291 & 0 & 0.00 & 275 & 94.50 \\
\hline Suntech Power & & & & & \\
\hline Holdings & 2 & 0 & 0.00 & 2 & 100.00 \\
\hline TCL - Alcatel/Thomson & 86 & 21 & 24.42 & 63 & 73.26 \\
\hline Wuhan Guide Infrared & 4 & 0 & 0.00 & 4 & 100.00 \\
\hline ZTE & 166 & 94 & 56.63 & 156 & 93.98 \\
\hline Total & 1,233 & 227 & 18.41 & 1,101 & 89.29 \\
\hline
\end{tabular}

Notes: (1), Total number of citations by the Chinese firm; (2), number of citations where the Chinese firm cites a firm established in an European host country; (3), ratio (2)/(1) in percent; (4), number of citations where two-dig sector of Chinese firm matches two-dig sector of cited firm; (5), ratio (4)/(1) in percent

Table VI.

Sources: Own calculations based on OECD REGPAT July 2013, Thomson Reuters M\&A Database, 2012, web sites of the respective firms

firms that are not part of a M\&A (Table VII). According to Table VII, M\&As represent 2.64 percent of all citations involving a local firm $(=57 / 2,157)$ and only 1.04 percent of all citations $(=57 / 5,503)$. The remaining 38.16 percent (of the 39.2 percent of citations that are local) involve Chinese firms that are located in the same recipient country as the cited firms. In the sample without Huawei, 18.4 percent of the citations that are local include 4.6 percent that involve M\&A local firms and 13.8 percent that include non-M\&A local firms (Table VII). In this case, M\&As represent 25 percent of all citations involving a local firm $(=57 / 227)$, and the remaining 75 percent of citations involve local firms that are not related to a M\&A.

M\&As may be an important mode of entry for accessing foreign knowledge, as demonstrated by several studies (Farrell and Shapiro, 2001; Martynova and 


\begin{tabular}{|c|c|c|c|c|c|c|c|}
\hline Company name & $\begin{array}{l}\text { No. of total } \\
\text { citations (1) }\end{array}$ & $\begin{array}{l}\% \text { citations } \\
\text { of local } \\
\text { firms ( } 2)\end{array}$ & $\begin{array}{l}\text { No. of } \\
\text { citations of } \\
\text { local firms } \\
\text { (M\&A) (3) }\end{array}$ & $\begin{array}{l}\% \text { citations } \\
\text { of local } \\
\text { firms } \\
(\mathrm{M} \& \mathrm{~A})(4)\end{array}$ & $\begin{array}{l}\text { No. of } \\
\text { citations of } \\
\text { local firms } \\
\text { (no M\&A) (5) }\end{array}$ & $\begin{array}{l}\% \text { citations } \\
\text { of local } \\
\text { firms (no } \\
\text { M\&A) (6) } \\
\end{array}$ & $\begin{array}{r}\text { Chinese } \\
\text { MNEs' } \\
\text { innovative } \\
\text { capabilities }\end{array}$ \\
\hline \multicolumn{8}{|l|}{ (a) Total sample } \\
\hline \multicolumn{8}{|l|}{ Angang Steel } \\
\hline \multicolumn{8}{|l|}{ Baosteel Group } \\
\hline Corporation & 5 & 0.00 & 0 & 0.00 & 0 & 0.00 & \\
\hline Blue Star Silicone & 16 & 37.50 & 4 & 25.00 & 2 & 12.50 & \\
\hline Byd Company & 448 & 4.67 & 0 & 0.00 & 21 & 4.69 & \\
\hline & \multicolumn{7}{|c|}{ Marine Containers } \\
\hline Group & 37 & 2.70 & 1 & 2.70 & 0 & 0.00 & \\
\hline \multicolumn{8}{|l|}{ China Mobile } \\
\hline Corporation & 24 & 41.67 & 10 & 41.67 & 0 & 0.00 & \\
\hline CITIC Group & 10 & 0.00 & 0 & 0.00 & 0 & 0.00 & \\
\hline \multicolumn{8}{|l|}{ Chongqing Lifan } \\
\hline Industry & 5 & 0.00 & 0 & 0.00 & 0 & 0.00 & \\
\hline \multicolumn{8}{|l|}{ Founder } \\
\hline $\begin{array}{l}\text { Electronics } \\
\text { Gree Electric }\end{array}$ & 1 & \multicolumn{4}{|c|}{ Gree Electric } & & \\
\hline Appliance & 9 & 55.56 & 0 & 0.00 & 5 & 55.56 & \\
\hline \multicolumn{8}{|l|}{ Guangzhou SAT } \\
\hline \multicolumn{8}{|l|}{ Infrared } \\
\hline (SATIR) & 14 & 71.43 & 0 & 0.00 & 10 & 71.43 & \\
\hline Haier Group & 8 & 75.00 & 1 & 12.50 & 5 & 62.50 & \\
\hline Hisense & 3 & 66.67 & 2 & 66.67 & 0 & 0.00 & \\
\hline Huaqi & 1 & 100.00 & 0 & 0.00 & 1 & 100.00 & \\
\hline \multicolumn{8}{|l|}{ Huawei } \\
\hline \multicolumn{8}{|l|}{ Technologies Co. } \\
\hline Lenovo Group Ltd & 60 & 50.00 & 30 & 50.00 & 0 & 0.00 & \\
\hline Petrochina & 14 & 38.46 & 0 & 0.00 & 5 & 35.71 & \\
\hline Sany & 19 & 52.63 & 0 & 0.00 & 10 & 52.63 & \\
\hline \multicolumn{8}{|l|}{ Sinochem } \\
\hline International & 3 & 66.67 & 2 & 66.67 & 0 & 0.00 & \\
\hline Sinopec & 291 & 0.00 & 0 & 0.00 & 0 & 0.00 & \\
\hline \multicolumn{8}{|l|}{ Suntech Power } \\
\hline Holdings & 2 & 0.00 & 0 & 0.00 & 0 & 0.00 & \\
\hline \multicolumn{8}{|l|}{ TCL - Alcatel/ } \\
\hline Thomson & 86 & 24.42 & 4 & 4.65 & 17 & 19.77 & \\
\hline \multicolumn{8}{|l|}{ Wuhan Guide } \\
\hline Infrared & 4 & 0.00 & 0 & 0.00 & 0 & 0.00 & \\
\hline ZTE & 166 & 56.63 & 0 & 0.00 & 94 & 56.63 & \\
\hline \multirow[t]{2}{*}{ Total } & 5,503 & 39.20 & 57 & 1.04 & 2,100 & 38.16 & Table VI \\
\hline & & & & & & (continued) & $\begin{array}{r}\text { Decomposition of } \\
\text { the link }\end{array}$ \\
\hline
\end{tabular}


IJOEM

10,2

\begin{tabular}{|c|c|c|c|c|c|c|}
\hline Company name & $\begin{array}{l}\text { No. of total } \\
\text { citations (1) }\end{array}$ & $\begin{array}{l}\% \text { citations } \\
\text { of local } \\
\text { firms (2) }\end{array}$ & $\begin{array}{l}\text { No. of } \\
\text { citations of } \\
\text { local firms } \\
\text { (M\&A) (3) }\end{array}$ & $\begin{array}{c}\% \text { citations } \\
\text { of local } \\
\text { firms } \\
(\mathrm{M} \& A)(4)\end{array}$ & $\begin{array}{c}\text { No. of } \\
\text { citations of } \\
\text { local firms } \\
\text { (no M\&A) (5) }\end{array}$ & $\begin{array}{c}\% \text { citations } \\
\text { of local } \\
\text { firms (no } \\
\text { M\&A) (6) }\end{array}$ \\
\hline
\end{tabular}

(b) Firms without Huawei Angang Steel

260
Company Ltd

Baosteel Group

Corporation

Blue Star Silicone

Byd Company

China International

Marine Containers

Group

China Mobile

Communications

Corporation

CITIC Group

Chongqing Lifan

Industry

Founder

Electronics

Gree Electric

Appliance

Guangzhou SAT

Infrared Technology

(SATIR)

Haier Group

Hisense

Huaqi

Lenovo Group Ltd

Petrochina

Sany

Sinochem

International

Sinopec

Suntech Power

Holdings

TCL - Alcatel/

Thomson

Wuhan Guide

Infrared

ZTE

Total

$\begin{array}{rr}7 & 42.86 \\ 5 & 0.00 \\ 16 & 37.50 \\ 448 & 4.67\end{array}$

37

2.70

1

2.70

41.67

0.00

0.00

0.00

0.00

0.00

12.50

66.67

0.00

50.00

0.00

0.00

66.67

0.00

0.00

4.65

0.00

0.00

4.62

$\begin{array}{rr}3 & 66.67 \\ 291 & 0.00 \\ & \\ 2 & 0.00 \\ 86 & 24.42 \\ & \\ 4 & 0.00 \\ 166 & 56.63 \\ 1,233 & 18.40\end{array}$

56.63
18.40

$\begin{array}{rr}0 & 0.00 \\ 0 & 0.00 \\ 57 & 4.62\end{array}$

$\begin{array}{rr}0 & 0.00 \\ 0 & 0.00 \\ 2 & 12.50 \\ 21 & 4.69\end{array}$

0

0.00

0.00

0.00

0.00

0.00

$5 \quad 55.56$

$10 \quad 71.43$

$5 \quad 62.50$

$0 \quad 0.00$

$1 \quad 100.00$

$\begin{array}{ll}0 & 0.00\end{array}$

$5 \quad 35.71$

$10 \quad 52.63$

$\begin{array}{rr}0 & 0.00 \\ 0 & 0.00 \\ & \\ 0 & 0.00 \\ & \\ 17 & 19.77 \\ & \\ 0 & 0.00 \\ 94 & 56.63 \\ 170 & 13.79\end{array}$

Notes: (1), Total number of citations by the Chinese firm; (2), report of column 2 from Table VI; (3), number of citations where the Chinese firm cites an acquired firm established in an European host country; (4), ratio (3)/(1) in percent; (5), number of citations where the Chinese firm cites a firm established in an European host country (excluding acquired firms); (6), ratio (5)/(1) in percent. The sum of columns (4) and (6) are equal to column (2)

Table VII.

Sources: Own calculations based on OECD REGPAT July 2013, Thomson Reuters M\&A Database 2012 , web sites of the respective firms 
Renneboog, 2006; Motis, 2007; Wang and Boateng, 2007). The focus of our study is narrower because we examine whether M\&As may generate a new innovation based on the existing knowledge held by the local partner. Considering the entire sample, the role of M\&As in the ability of Chinese MNEs to generate new knowledge represents a negligible portion of the citations involving a domestic firm located in the recipient country. However, the role of M\&As becomes less moderate after removing Huawei and its related bias in the citations.

\section{Chinese MNEs' innovative capabilities}

261

5. Network effects contribute to generating new knowledge within the Chinese affiliates located in clusters or innovative centers. Linkages with independent domestic firms and institutions located in the recipient country - in particular within clusters - are significant drivers for generating innovations based on foreign knowledge

As indicated in Table VII, approximately 38 percent of citations involve local firms not related to a M\&A. These citations represent 97 percent of the citations based on local firms. We have identified Chinese FDI located within clusters. The clusters are identified based on the European Cluster Observatory (2011). The analysis indicates that 30.5 percent of Chinese investments in European countries match a cluster localization. Our results indicate that 759 citations involve domestic firms based in clusters of recipient countries in which Chinese MNEs are located, representing 13.8 percent $(=759 / 5,503)$ of all citations and 35 percent $(=759 / 2,157)$ of all citations involving a local firm in the recipient country (Table VII).

Combining the results highlighted in Tables VII and VIII, the analysis indicates that 39.2 percent of the entire sample involves domestic firms located in the recipient country. These citations involve three different sources of knowledge: 1.04 percent represent local firms involved in an M\&A with Chinese MNEs; 13.8 percent involve independent local firms located in the same cluster as the Chinese MNEs; and the remaining 24.36 percent involve local firms located in the same region as a Chinese MNE's affiliate but not in a specific cluster.

The remaining 60.8 percent of the sample demonstrates that firms do not need to be collocated to exchange assets (Narula, 2013, p. 12; Santangelo, 2012). As noted by Narula, "[w]here knowledge can be codified, firms can acquire knowledge assets through markets" (2013, p. 12).

\section{Contribution, limitations, and further studies}

This paper provides some interesting insights into the strategic asset-seeking motivations of Chinese MNEs to invest in European countries. Using a patent and citation approach, the analysis reveals that the ability of Chinese MNEs to generate innovation based on their own knowledge is low compared to firms from developed countries. This confirms that Chinese firms lack own technological capabilities to innovate. Moreover, as expected, the Chinese innovations are primarily based on foreign knowledge, mainly from firms originating from developed countries. This clearly demonstrates the need to access strategic assets from developed countries. This foreign knowledge can be absorbed through different channels: either through M\&A, through greenfields or through establishment in clusters. The two major channels to benefit from knowledge transfers are M\&A and establishment in clusters. Rather unexpected, our findings suggest that M\&As have a limited effect on the ability of Chinese MNEs to generate new knowledge based on the acquired or merged foreign firms. However, linkages with independent domestic firms and institutions located in 
IJOEM

10,2

262

\begin{tabular}{|c|c|c|c|c|c|}
\hline Company name & Sector & $\begin{array}{l}\text { Host } \\
\text { country }\end{array}$ & Host region & $\begin{array}{l}\text { No. of } \\
\text { cited firms } \\
\text { in cluster }\end{array}$ & $\begin{array}{l}\text { No. of } \\
\text { cited } \\
\text { patents }\end{array}$ \\
\hline Blue Star Silicone & Chemicals & FR & $\begin{array}{l}\text { Ile-de-France/Rhône- } \\
\text { Alpes/Aquitaine }\end{array}$ & 1 & 2 \\
\hline Byd Company & $\begin{array}{l}\text { Electronic and other } \\
\text { electrical components }\end{array}$ & NL & South Holland & 0 & 0 \\
\hline $\begin{array}{l}\text { China International } \\
\text { Marine Containers } \\
\text { Group }\end{array}$ & $\begin{array}{l}\text { Fabricated metal } \\
\text { products }\end{array}$ & $\mathrm{DE}$ & Hamburg & 0 & 0 \\
\hline Haier Group & $\begin{array}{l}\text { Electronic and other } \\
\text { electrical components }\end{array}$ & IT & Veneto & 1 & 1 \\
\hline $\begin{array}{l}\text { Huawei Technologies } \\
\text { Co. Ltd }\end{array}$ & Business services & IT & Lazio & 1 & 1 \\
\hline $\begin{array}{l}\text { Huawei Technologies } \\
\text { Co. Ltd }\end{array}$ & Business services & $\mathrm{DE}$ & Bayern & 0 & 0 \\
\hline $\begin{array}{l}\text { Huawei Technologies } \\
\text { Co. Ltd }\end{array}$ & Business services & FR & Ile-de-France & 22 & 348 \\
\hline $\begin{array}{l}\text { Huawei Technologies } \\
\text { Co. Ltd }\end{array}$ & Business services & FR & Ile-de-France & 0 & 0 \\
\hline $\begin{array}{l}\text { Huawei Technologies } \\
\text { Co. Ltd }\end{array}$ & Business services & $\mathrm{SE}$ & Sweden & 7 & 318 \\
\hline $\begin{array}{l}\text { Huawei Technologies } \\
\text { Co. Ltd }\end{array}$ & Business services & FR & Ile-de-France & 0 & 0 \\
\hline $\begin{array}{l}\text { Huawei Technologies } \\
\text { Co. Ltd }\end{array}$ & Business services & $\mathrm{DE}$ & $\begin{array}{l}\text { Nordrhein- } \\
\text { Westfalen }\end{array}$ & 2 & 10 \\
\hline $\begin{array}{l}\text { Huawei Technologies } \\
\text { Co. Ltd }\end{array}$ & Business services & TR & Turkey & 0 & 0 \\
\hline $\begin{array}{l}\text { Huawei Technologies } \\
\text { Co. Ltd }\end{array}$ & Business services & GB & London & 0 & 0 \\
\hline $\begin{array}{l}\text { Huawei Technologies } \\
\text { Co. Ltd }\end{array}$ & Business services & GB & London & 25 & 47 \\
\hline Lenovo Group Ltd & $\begin{array}{l}\text { Industrial and } \\
\text { Commercial Machinery } \\
\text { and Computer } \\
\text { Equipment }\end{array}$ & $\mathrm{DE}$ & Bade-Wurtemberg & 1 & 1 \\
\hline Lenovo Group Ltd & $\begin{array}{l}\text { Industrial and } \\
\text { Commercial Machinery } \\
\text { and Computer } \\
\text { Equipment }\end{array}$ & FR & Ile-de-France & 0 & 0 \\
\hline Lenovo Group Ltd & $\begin{array}{l}\text { Industrial and } \\
\text { Commercial Machinery } \\
\text { and Computer } \\
\text { Equipment }\end{array}$ & $\mathrm{SE}$ & Stockholm & 2 & 4 \\
\hline Lenovo Group Ltd & $\begin{array}{l}\text { Industrial and } \\
\text { Commercial Machinery } \\
\text { and Computer } \\
\text { Equipment }\end{array}$ & SK & Slovakia & 0 & 0 \\
\hline Lenovo Group Ltd & $\begin{array}{l}\text { Industrial and } \\
\text { Commercial Machinery } \\
\text { and Computer } \\
\text { Equipment }\end{array}$ & $\mathrm{DE}$ & $\begin{array}{l}\text { North Rhine- } \\
\text { Westphalia }\end{array}$ & 0 & 0 \\
\hline
\end{tabular}

\section{Table VIII.}

Chinese investments in specific clusters, number of cited firms localized within these clusters and their citations

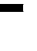




\begin{tabular}{|c|c|c|c|c|c|}
\hline Company name & Sector & $\begin{array}{l}\text { Host } \\
\text { country }\end{array}$ & Host region & $\begin{array}{l}\text { No. of } \\
\text { cited firms } \\
\text { in cluster }\end{array}$ & $\begin{array}{c}\text { No. of } \\
\text { cited } \\
\text { patents }\end{array}$ \\
\hline Sinopec & Oil and Gas Extraction & RU & Udmurt Republic & 0 & \\
\hline Suntech Power & Electronic and other & & & & \\
\hline Holdings & electrical components & IT & Lombardia & 0 & 0 \\
\hline Suntech Power & Electronic and other & & & & \\
\hline Holdings & electrical components & IT & Lombardia & 0 & 0 \\
\hline $\begin{array}{l}\text { Suntech Power } \\
\text { Holdinos }\end{array}$ & Electronic and other & IT & Lombardia & 0 & 0 \\
\hline TCL - Alcatel/ & Motion pictures & FR & Ile-de-France & 0 & 0 \\
\hline \multicolumn{6}{|l|}{ Thomson } \\
\hline ZTE & Business services & $\mathrm{SE}$ & Sweden & 2 & 13 \\
\hline ZTE & Business services & GB & South East (UK) & 2 & 2 \\
\hline ZTE & Business services & $\mathrm{SE}$ & Sweden & 0 & 0 \\
\hline ZTE & Business services & $\mathrm{DE}$ & $\begin{array}{l}\text { Nordrhein- } \\
\text { Westfalen }\end{array}$ & 0 & 0 \\
\hline ZTE & Business services & $\mathrm{DE}$ & Bayern & 2 & 6 \\
\hline ZTE & Business services & $\mathrm{DE}$ & $\begin{array}{l}\text { Nordrhein- } \\
\text { Westfalen }\end{array}$ & 0 & 0 \\
\hline ZTE & Business services & FR & Ile-de-France & 3 & 6 \\
\hline ZTE & Business services & $\mathrm{DE}$ & $\begin{array}{l}\text { Nordrhein- } \\
\text { Westfalen }\end{array}$ & 0 & 0 \\
\hline ZTE & Business services & AT & Vienna & 0 & 0 \\
\hline ZTE & Business services & IT & Lazio & 0 & 0 \\
\hline ZTE & Business services & PL & Masowian & 0 & 0 \\
\hline ZTE & Business services & RO & South Romania & 0 & 0 \\
\hline ZTE & Business services & ES & Madrid & 0 & 0 \\
\hline ZTE & Business services & TR & Marmara & 0 & 0 \\
\hline \multirow[t]{2}{*}{ ZTE } & Business services & GB & London & 0 & 0 \\
\hline & & & Total & 71 & 759 \\
\hline
\end{tabular}

Note: The last two columns correspond respectively to the number of cited firms established in the specific region where the Chinese firm has invested, and to the total number of their patents cited by the Chinese firm

Sources: Own elaboration based on European Cluster Observatory (2011), European Patent Office (2012), M\&A Thomson-Reuters Database 2012, OECD REGPAT July 2013, and own observations

the recipient country, particularly within clusters, are a significant driver for generating innovations based on foreign knowledge.

Nevertheless, our findings have to be interpreted with caution. Some empirical limitations may diminish the robustness of our results. First, due to the small sample of Chinese firms analyzed, our findings cannot be generalized to all Chinese firms investing in European countries and can result in some important biases among firms regarding patenting and citing behaviors. To generalize our results, the analysis should be extended to patents registered with the US Patent and Trademark Office (USPTO) on a larger sample. Second, patents refer to codified knowledge and represent only a portion of the knowledge of a firm. Some discoveries are not patented and can be shared tacitly. The strategic asset-seeking motivation cannot be optimally and efficiently tested using patent analysis because some industries have a higher propensity to patent than others. The citation analysis is useful for study the transfer of knowledge. However, citations are not always registered by applicants. Patent 
IJOEM

10,2

264

examiners can add citations unbeknownst to applicants. The last empirical difficulty is to correctly define the link (either an M\&A or localization) between the citing and cited firms due to the non-exhaustive list of Chinese investments in European countries.

Based on our research, it would be interesting to investigate the subsidiaryheadquarter relationship, scrutinizing the paths of innovation within the firm's network. As noted by Najafi-Tavani et al. (2014, p. 123), "[w]hile the literature suggests that it is important to look at subsidiary-headquarters relationships when investigating subsidiary influence (Birkinshaw et al., 2005), this association has not been empirically investigated." The analysis could also investigate the role of subsidiaries within MNEs according to the distinction made by Mudambi et al. (2014, p. 103) between the "functional power" and "strategic power" of subsidiaries. Furthermore, this study focusses on assets obtained, upgraded, or created by Chinese affiliates in their European host countries and does not consider the spillovers created by these affiliates in their host countries. It would be worthwhile to analyze more deeply these effects, as in Giuliani et al. (2014).

Finally, this paper focusses on the role of Chinese OFDI as vehicle to upgrade firms' innovative capabilities. The study does not address the role of IFDI in China in providing positive technological externalities to domestic firms. As highlighted inter alia by Mathews (2002) and more recently by Zhang and Roelfsema (2014), linkages with foreign affiliates doing business in China may also be an important piece of the global puzzle governing Chinese firms' strategies abroad and their success in acquiring competitive assets abroad.

\section{References}

Alon, I., Mloldtsova, T. and Zhang, J. (2010), "Macroeconomic prospects for China's outward foreign direct investments", paper presented at China Goes Global Conference 2010, Harvard University, Cambridge, MA, October 6-8.

Alon, I., Fetscherin, M. and Gugler, P. (2012), Chinese International Investments, Palgrave Macmillan.

Amighini, A. and Franco, Ch. (2013), "A sector perspective on Chinese outward FDI: the automotive case”, China Economic Review, Vol. 27, pp. 148-161.

Amighini, A., Cozza C., Rabelloti, R. and Sanfilippo, M. (2014), "An analysis of Chinese outward FDIs in Europe with firm-level data”, Working Paper No. 2014/02, CIRCLE University of Lund, Lund.

Arikan, A.T. (2009), "Inter-firm knowledge exchanges and the knowledge creation capability of clusters", Academy of Management Review, Vol. 34 No. 4, pp. 658-676.

Asheim, B.T. and Gertler, M. (2005), "The geography of innovation: regional innovation systems”, in Fagerberg, J., Mowery, D. and Nelson, R. (Eds), The Oxford Handbook of Innovation, Oxford University Press, Oxford, pp. 291-317.

Audretsch, D.B. and Feldman, M.P. (1996), "R\&D Spillovers and the geography of innovation and production”, American Economic Review, Vol. 86 No. 3, pp. 630-640.

Avidity IP Ltd (2012), “The co-ownership of patents across Europe”, IP Europe Quarterly, pp. 1-14.

Birkinshaw, J. (1996), "How multinational subsidiary mandates are gained and lost", Journal of International Business Studies, Vol. 27 No. 3, pp. 467-495.

Birkinshaw, J. and Sölvell, Ö. (2000), "Preface”, International Studies of Management and Organization, Vol. 30 No. 2, pp. 3-9. 
Birkinshaw, J., Hood, N. and Young, S. (2005), "Subsidiary entrepreneurship, internal and external competitive forces, and subsidiary performance", International Business Review, Vol. 14 No. 2, pp. 227-248.

Bloomberg (2010), “50 most innovative companies”, Annual Rankings, available at: www.bloomberg. com/bw/magazine/content/10_17/b4175034779697.htm

Boisot, M. and Child, J. (1996), "From fiefs to clans and network capitalism: explaining China's emerging economic order", Administrative Science Quarterly, Vol. 41 No. 4, pp. 600-628.

Bräutigam, D. and Tang, X. (2014), “'Going global in groups': structural transformation and China's special economic zones overseas”, World Development, Vol. 63, pp. 78-91.

Buckley, P.J. and Casson, M.C. (1976), The Future of the Multinational Enterprise, Macmillan, London.

Buckley, P.J., Cross, A.R., Tan, H., Liu, X. and Voss, H. (2008), "Historic and emergent trends in Chinese outward direct investment”, Management International Review, Vol. 48 No. 6, pp. 715-748.

Buckley, P.J., Clegg, J., Cross, A.R., Liu, X., Voss, H. and Zheng, P. (2007), "The determinants of Chinese outward foreign direct investment", Journal of International Business Studies, Vol. 40 No. 2, pp. 353-354.

Cantwell, J.A. and Mudambi, R. (2011), "Physical attraction and the geography of knowledge sourcing in multinational enterprises", Global Strategy Journal, Vol. 1 Nos 3-4, pp. 206-232.

Cantwell, J.A., Glac, K. and Harding, R. (2004), "The internationalization of R\&D - the Swiss case", Management International Review, Vol. 44 No. 3, pp. 57-82.

Chamber of Commerce (2013), Chinese Outbound Investment in the European Union, Chamber of Commerce, Beijing, available at: www.europeandchamber.com.cn

Chang, J. (2011), "The early and rapid internationalization of Asian emerging MNEs", Competitiveness Review: An International Business Journal, Vol. 21 No. 2, pp. 171-187.

Chen, Y.Y. and Young, M.N. (2010), "Cross-border MandA by Chinese listed companies: a principal-principal perspective", Asia Pacific Journal of Management, Vol. 27 No. 3, pp. 523-539.

Cheung, Y.-W. and Suny, X.Q. (2009), “Empirics of China's outward direct investment”, Pacific Economic Review, Vol. 14 No. 3, pp. 312-341.

Child, J. and Rodrigues, S.B. (2005), "The Internationalization of Chinese firms: a case for theoretical extension?”, Management and Organization Review, Vol. 1 No. 3, pp. 381-410.

Collinson, S.C. and Rugman, A.M. (2011), "Relevance and rigor in international business teaching: using the CSA-FSA matrix", Journal of Teaching in International Business, Vol. 22 No. 1, pp. 29-37.

Collinson, S.C. and Wang, R.J.L. (2012), "Learning networks and technological capability in multinational enterprise subsidiaries”, Research Policy, Vol. 41 No. 9, pp. 1501-1518.

Contractor, F.J. (2013), "Punching above their weight: the sourcing of competitive advantage for emerging market multinationals", International Journal of Emerging Markets, Vol. 8 No. 4, pp. 304-328.

Criscuolo, P. (2004), "R\&D internationalisation and knowledge transfer: impact on MNEs and their home countries", Maastricht Economic Research Institute on Innovation and Technology, Maastricht.

Criscuolo, P. and Verspagen, B. (2008), "Does it matter where patent citations come from? Inventor vs examiner citations in European patents”, Research Policy, Vol. 37 No. 10, pp. 1892-1908.

Cui, L. and Jiang, F. (2009), "FDI entry mode choice of Chinese firms: a strategic behavior perspective", Journal of World Business, Vol. 44 No. 4, pp. 434-444. 
IJOEM

10,2
Cui, L. and Jiang, F. (2010), "Behind ownership decision of Chinese outward FDI: resources and institutions", Asia Pacific Journal of Management, Vol. 27 No. 4, pp. 751-774.

Cui, L., Meyer, K.E. and Wei, Hu, H. (2013), "What drives firms' intent to seek strategic assets by foreign direct investment? A study of emerging economy firms", Journal of World Business, Vol. 49 No. 4, pp. 488-501.

De Beule, F., Elia, S. and Piscitello, L. (2014), "Entry and access to competencies abroad: Emerging Market firms versus advanced market firms", Journal of International Management, Vol. 20 No. 2, pp. 137-152.

Deng, P. (2007), "Investing for strategic resources and its rationale: the case of outward FDI from Chinese companies", Business Horizons, Vol. 50 No. 1, pp. 71-81.

Deng, P. (2009), "Why do Chinese firms tend to acquire strategic assets in international expansion?”, Journal of World Business, Vol. 44 No. 1, pp. 74-84.

Dunning, J.H. (1998), "Location and the multinational enterprise: a neglected factor?", Journal of International Business Studies, Vol. 29 No. 1, pp. 45-66.

Dunning, J.H. and Narula, R. (1995), "The R\&D activities of foreign firms in the US”, International Studies in Management and Organisation, Vol. 25 Nos 1/2, pp. 39-73.

Dunning, J.H. and Lundan, S.M. (2008), Multinational Enterprises and the Global Economy, 2nd ed., Edward Elgar, Cheltenham and Northampton, MA.

Dunning, J.H., Changsu, K. and Park D. (2008), "Old wine in new bottles: a comparison of emerging-market TNCs today and developed-country TNCs thirty years ago", in Sauvant, K. (Ed.), The Rise of Transnational Corporations from Emerging Markets: Threat of Opportunity? Edward Eldgar, Cheltenham, pp. 158-180.

Erdener, C. and Shapiro, D.M. (2005), "The internationalization of Chinese family enterprises and dunning's eclectic MNE paradigm”, Management and Organization Review, Vol. 1 No. 3, pp. 411-436.

European Cluster Observatory (2011), “Cluster mapping”, available at: www.clusterobservatory. eu/index.html (accessed January 2014).

European Patent Office (2013), EPO - Espacenet, December, available at: www.epo.org/searching/ free/espacenet.html

Farrell, J. and Shapiro, C. (2001), "Scale economies and synergies in horizontal merger analysis", Antitrust Law Journal, Vol. 68, pp. 685-710.

Feldman, M.P. (2000), "Location and innovation: the new economic geography of innovation, spillovers, and agglomeration", in Clark, G., Feldman, M. and Gertler, M., (Eds), The Oxford Handbook of Economic Geography, Oxford University Press, Oxford, pp. 373-394.

Foss, K., Foss, N. and Nell, P. C. (2012), "MNC organizational form and subsidiary motivation problems: controlling intervention hazards in the network MNC", Journal of International Management, Vol. 18 No. 3, pp. 247-259.

Gaffney, N., Kedia, B. and Clampit, J. (2013), “A resource dependence perspective of EMNE FDI strategy”, International Business Review, Vol. 22 No. 6, pp. 1092-1100.

Gaur, A.S., Kumar, V. and Singh, D. (2014), "Institutions, resources, and internationalization of emerging economy firms", Journal of World Business, Vol. 49 No. 1, pp. 12-20.

Ghauri, P. and Santangelo, G. (2012), "Multinationals and the changing rules of competition", Management International Review, Vol. 52 No. 2, pp. 145-154.

Giroud, A. and Scott-Kennel, J. (2009), "MNE linkages in international business: a framework for analysis”, International Business Review, Vol. 18 No. 6, pp. 555-566. 
Giuliani, E., Gorgoni, S., Günther, Ch. and Rabellotti, R. (2014), "Emerging versus advanced country MNEs investing in Europe: a typology of subsidiary global-local connections", International Business Review, Vol. 23 No. 4, pp. 680-691.

Globerman, S. and Shapiro, D. (2009), "Economic and strategic considerations surrounding Chinese FDI in the United States", Asia Pacific Journal of Management, Vol. 26 No. 1, pp. 163-183.

Guan, J.C., Mok, C.K., Yam Richard, C.M., Chin, K.S. and Pun, K.F. (2006), “Technology transfer and innovation performance: evidence from Chinese firms", Technological Forecasting and Social Change, Vol. 73 No. 6, pp. 666-678.

Gugler, Ph., Keller, M. and Tinguely, X. (2013), "The role of clusters in the global innovation strategies of MNEs: evidence from the Basel pharmaceutical cluster", paper presented at the Annual EIBA Conference 2013, Bremen, December, 12-14 (forthcoming in 2015 in Competitiveness Review).

Hallin, C., Holm, U. and Sharma, D.D. (2011), "Embeddedness of innovation receivers in the multinational corporation: Effects on business performance", International Business Review, Vol. 20 No. 3, pp. 362-373.

Holtbrügge, D. and Kreppel, H. (2012), "Determinants of outward foreign direct investment from BRIC countries: an explorative study", International Journal of Emerging Markets, Vol. 7 No. 1, pp. 4-30.

Hong, E. and Sun, L. (2006), "Dynamics of Internationalization and outward investment: chinese corporations' strategies", The China Quarterly, Vol. 187 No. 2, pp. 610-634.

Huang, Y. and Wang, B. (2011), "Chinese outward direct investment: is there a China model?", China and the World Economy, Vol. 19 No. 4, pp. 1-21.

Huang, Y. and Wang, B. (2013), "Investing overseas without moving factories abroad: the case of Chinese outward direct investment”, Asian Development Review, Vol. 30 No. 1, pp. 85-107.

Iammarino, S. and McCann, Ph. (2006), "The structure and evolution of industrial clusters: transactions, technology and knowledge spillovers", Research Policy, Vol. 35 No. 7, pp. 1018-1036.

Jaffe, A. and Trajtenberg, M. (1999), "International knowledge flows: evidence from patent citations", Economics of Innovation and New Technology, Vol. 8 Nos 1-2, pp. 105-136.

Jaffe, A.B., Trajtenberg, M. and Henderson, R. (1993), "Geographic localization of knowledge spillovers as evidenced by patent citations”, Quarterly Journal of Economics, Vol. 108 No. 3, pp. 577-598.

Jaffe, A.B., Fogarty, M.S. and Banks, B.A. (1998), "Evidence from patents and patent citations on the impact of NASA and other federal labs on commercial innovation", Journal of Industrial Economics, Vol. 46 No. 2, pp. 183-205.

Jiang, G., Zhang, F. and Thakur, P. (2007), "The location choice of cross-border M\&A: the case of Chinese firms", EIBA Conference 2007, Catania, 13-15 December.

Kogut, B. and Zander, U. (1993), "Knowledge of the firm and the evolutionary theory of the multinational corporation", Journal of International Business Studies, Vol. 24 No. 4, pp. 625-645.

Kohlbacher, M., Weitlaner, D., Hollosi, A., Grünwald, S. and Grahsl, H.-P. (2013), "Innovation in clusters: effects of absorptive capacity and environmental moderators", Competitiveness Review: An International Business Journal, Vol. 23 No. 3, pp. 199-217.

Kuemmerle, W. (1997), "Building effective R\&D capabilities abroad”, Harvard Business Review, Vol. 75 No. 2, pp. 61-70.

Kuemmerle, W. (1999), "The drivers of foreign direct investment into R\&D: an empirical investigation", Journal of International Business Studies, Vol. 30 No. 1, pp. 1-24. 
IJOEM

10,2

Li, P.P. (2007), "Toward an integrated theory of multinational evolution: the evidence of Chinese multinational enterprises as latecomers", Journal of International Management, Vol. 13 No. 3, pp. 296-318.

Liu, X. and Buck, T. (2007), "Innovation performance and channels for international technology spillovers: evidence from Chinese high-tech industries”, Research Policy, Vol. 36 No. 3, pp. 355-366.

Liu, X. and Buck, T. (2009), "The internationalization strategies of Chinese firms: Lenovo and BOE”, Journal of Chinese Economic and Business Studies, Vol. 7 No. 2, pp. 167-181.

Liu, Y.P. and Woywode, M. (2013), "Light-touch integration of Chinese cross-border M\&A: the influences of culture and absorptive capacity", Thunderbird International Business Review, Vol. 55 No. 4, pp. 469-483.

Lyles, M., Li, D. and Yan, H. (2014), "Chinese outward FDI performance: the role of learning", Management and Organization Review, Vol. 10 No. 3, pp. 411-437.

Makino, S., Lau, C.M. and Yeh, R.-S. (2002), "Asset-exploitation versus asset-seeking: implications for location choice of foreign direct investment from newly industrialized economies", Journal of International Business Studies, Vol. 33 No. 3, pp. 403-421.

Martynova, M. and Renneboog, L.D.R. (2006), "Mergers and acquisitions in Europe", in Renneboog, L.D.R. (Ed.), Advances in Corporate Finance and Asset Pricing, Elsevier, Amsterdam, pp. 13-75.

Maskell, P. and Malmberg, A. (1999), "Localised learning and industrial competitiveness", Cambridge Journal of Economics, Vol. 23 No. 2, pp. 167-185.

Mathews, J. (2002), Dragon Multinationals: A New Model for Global Growth, Oxford University Press, Oxford.

Mathews, J. (2006), "Dragon multinationals: new players in 21st century globalization", Asia Pacific Journal of Management, Vol. 23 No. 1, pp. 5-27.

Meyer, K.E., Wright, M. and Pruthi, S. (2009), "Managing knowledge in foreign entry strategies: a resource-based analysis", Strategic Management Journal, Vol. 30 No. 5, pp. 557-574.

Meyer, K.E., Mudambi, R. and Narula, R. (2011), "Multinational enterprises and local contexts: the opportunities and challenges of multiple embeddedness", Journal of Management Studies, Vol. 48 No. 2, pp. 235-252.

Michel, J. (2009), Investissements Directs à L'étranger Dans les Activités de Recherche et de Développement: Fondements Théoriques et Application Aux Entreprises Suisses, Peter Lang.

Motis, J. (2007), "Mergers and acquisitions motives", working paper, University of Crete, Crete.

Mudambi, R. (2008), "Location, control, and innovation in knowledge-intensive industries", Journal of Economic Geography, Vol. 8 No. 5, pp. 699-725.

Mudambi, R. (2011), "Hierarchy, coordination, and innovation in the multinational enterprise", Global Strategy Journal, Vol. 1 Nos 3/4, pp. 317-323.

Mudambi, R. and Navarra, P. (2004), "Is knowledge power? Knowledge flows, subsidiary power, and rent-seeking within MNCs", Journal of International Business Studies, Vol. 35 No. 5, pp. 385-406.

Mudambi, R. and Swift, T. (2010), “Technological clusters and multinational enterprise R\&D strategy", in Devinney, T., Pedersen, T. and Tihanyi, T. (Eds), The Past, The Present and The Future of International Business and Management, Vol. 23, Emerald Group Publishing Limited, pp. 461-478.

Mudambi, R., Pedersen, T. and Andersson, U. (2014), "How subsidiaries gain power in multinational corporations”, Journal of World Business, Vol. 49 No. 1, pp. 101-113. 
Najafi-Tavani, Z., Giroud, A. and Andersson, U. (2014), "The interplay of networking activities and internal knowledge actions for subsidiary influence within MNCs", Journal of World Business, Vol. 49 No. 1, pp. 122-131.

Narula, R. (2013), "Exploring the paradox of competence-creating subsidiaries: balancing bandwidth and dispersion in MNEs", Working Paper Series No. 046, Unu-Merit, Maastricht.

Nicholson, R.R. and Salaber, J. (2013), "The motives and performance of cross-border acquirers from emerging economies: comparison between Chinese and Indian firms", International Business Review, Vol. 22 No. 6, pp. 963-980.

Nicolas, F. (2014), “China's direct investment in the European Union: challenges and policy responses", China Economic Journal, Vol. 7 No. 1, pp. 103-125.

Nolan, P. (2001), China and the Global Economy, Palgrave, Basingstoke.

Noorderhaven, N.G. and Harzing, A.W. (2009), "Knowledge sharing and social interaction within MNEs", Journal of International Business Studies, Vol. 40 No. 5, pp. 719-741.

OECD (2008a), “Chapter 3: China's Outward Direct Investment”, in OECD (Ed.), OECD Investment Policy Reviews: China 2008, OECD Publications, Paris, pp. 65-142.

OECD (2008b), OECD Reviews of Innovation Policy, OECD Publications.

OECD (2009), OECD Patent Statistics Manual, OECD Publishing.

OECD (2013), “OECD REGPAT Database July 2013”, OECD.

Onal, B. (2009), Cross-Border Mergers and Acquisitions Across Developed and Developing Countries: An Empirical Analysis, Georgia State University.

Park, B. and Choi, J. (2014), "Foreign direct investment motivations and knowledge acquisition from MNEs in overseas subsidiaries", Canadian Journal of Administrative Sciences, Vol. 31 No. 2, pp. 104-115.

Perri, A. and Andersson, U. (2014), "Knowledge outflows from foreign subsidiaries and the tension between knowledge creation and knowledge protection: evidence from the semiconductor industry", International Business Review, Vol. 23 No. 1, pp. 63-75.

Poncet, S. (2007), "Inward and Outward FDI in China", working paper, Panthéon-SorbonneEconomie, Université Paris I CNRS and CEPII, Paris.

Porter, M. (2008), On Competition: Updated and Expanded Edition, Harvard Business School Press, Boston.

Rao, P.M., Chandra, R. and Shin, J. (2012), "R\&D offshoring in multinational enterprises: relevance of transaction cost and internalization theories", Competitiveness Review: An International Business Journal, Vol. 22 No. 4, pp. 376-395.

Robins, F. (2013), "The uniqueness of Chinese outward foreign direct investment", Asian Business and Management, Vol. 12 No. 5, pp. 525-537.

Rugman, A.M. (1981), Inside the Multinationals: The Economics of Internal Markets, Croon Helm, London.

Rugman, A.M. (2010), "Reconciling internalization theory and the eclectic paradigm", Multinational Business Review, Vol. 18 No. 2, pp. 1-12.

Rugman, A.M. and Doh, J.P. (2008), Multinationals and Development, Yale University Press, New Haven and London.

Rugman, A.M. and Li, J. (2007), "Will China's multinationals succeed globally or regionally?", European Management Journal, Vol. 25 No. 5, pp. 333-343.

Rugman, A.M. and Verbeke, A. (1992), "A note on the transnational solution and the transaction cost theory of multinational strategic management", Journal of International Business Studies, Vol. 23, pp. 761-771. 
IJOEM

10,2

Rugman, A.M. and Verbeke, A. (2001), "Subsidiary-specific advantages in multinational enterprises”, Strategic Management Journal, Vol. 22 No. 3, pp. 237-250.

Rugman, A.M., Nguyen, Q.T.K. and Wei, Z. (2014), "Chinese multinationals and public policy”, International Journal of Emerging Markets, Vol. 9 No. 2, pp. 205-215.

Rugman, A.M., Verbeke, A. and Yuan, W. (2011), "Re-conceptualizing Bartlett and Ghoshal's classification of national subsidiary roles in the multinational enterprise", Journal of Management Studies, Vol. 48 No. 2, pp. 253-277.

Rui, H. and Yip, G.S. (2008), "Foreign acquisition by Chinese firms: a strategic intent perspective", Journal of World Business, Vol. 43 No. 2, pp. 213-226.

Salter, M. and Weinhold, W. (1979), Diversification Through Acquisition, Free Press, New York, NY.

Sampat, B.N. (2005), "Determinants of patent quality: an empirical analysis", working paper, Columbia University, New York, NY.

Santangelo, G.D. (2012), "The tension of information sharing: effects on subsidiary embeddedness", International Business Review, Vol. 21 No. 2, pp. 180-195.

Segarra-Cipres, M., Roca-Puig, V. and Bou-Llusar, J.C. (2014), "External knowledge acquisition and innovation output: an analysis of moderating effect of internal knowledge transfer", Knowledge Management Research and Practice, Vol. 12, pp. 203-214.

Shenkar, O. (2009), "Becoming multinational: challenges for Chinese firms", Journal of Chinese Economic and Foreign Trade Studies, Vol. 2 No. 3, pp. 149-162.

Sun, S.L., Peng, M.W., Ren, B. and Yan, D. (2012), “A comparative ownership advantage framework for cross-border M\&As: the rise of Chinese and Indian MNEs", Journal of World Business, Vol. 47 No. 1, pp. 4-16.

Tao, B., Zhanming, J. and Xiaoguang, Q. (2013), “Chinese firms' outward FDI entry mode choice: the role of ownership and network", Journal of Innovation Management, Vol. 1 No. 1, pp. 108-124.

Tavares Lehmann, A.T. and Teixeira, A.A.C. (2006), Multinationals, Clusters and Innovation: Does Public Policy Matter? Palgrave Macmillan.

Thomson Reuters (2012), "Thomson Reuters M\&A Database”, CEDIF Center, University of Lausanne.

Tinguely, X. (2013), The New Geography of Innovation: Clusters, Competitiveness and Theory, Palgrave Macmillan, Basingstoke.

UNCTAD (2006), "World Investment Report 2006: FDI from Developing and Transition Economies: Implications for Development", New York, NY and Geneva.

UNCTAD (2013), "World Investment Report 2013: Global Value Chains: Investment and Trade for Development”, New York, NY and Geneva.

Verbeke, A. (2009), International Business Strategy: Rethinking the Foundations of Global Corporate Success, Cambridge University Press, Cambridge.

Wang, C., Hong, J., Kafouros, M. and Boateng, A. (2012), "What drives outward FDI of Chinese firms? Testing the explanatory power of three theoretical frameworks", International Business Review, Vol. 21 No. 3, pp. 425-438.

Wang, Q. and Boateng, A. (2007), "Cross-border M\&As by Chinese firms: an analysis of strategic motivation and performance", International Management Review, Vol. 3 No. 4, pp. 19-29.

Wang, Y., Cao, W., Zhou, Z. and Ning L. (2013), "Does external technology acquisition determine export performance? Evidence from Chinese manufacturing firms", International Business Review, Vol. 22 No. 6, pp. 1079-1091.

WEF (2013), Global Competitiveness Report 2013-2014, World Economic Forum, Geneva. 
Wei, Y. and Liu, X. (2006), "Productivity spillovers from R\&D, exports and FDI in China's manufacturing sector", Journal of International Business Studies, Vol. 37, pp. 544-557.

Wu, H.-L. and Chen, C.-H. (2001), "An assessment of outward foreign direct investment from China's transitional economy”, Europe-Asia Studies, Vol. 53 No. 8, pp. 1235-1254.

Wu, X. and Ding, W. (2009), "Chinese firms' internationalization paths by strategic asset-seeking outward foreign direct investment", PICMET 2009 Proceedings, August 2-6, Portland, Oregon, OR, pp. 173-179.

Chinese MNEs' innovative capabilities

Yeung, H.W.-C. and Liu, W. (2008), "Globalizing China: the rise of mainland firms in the global economy", working paper, pp.1-49 (published in Eurasian Geography and Economics, Vol. 49 No. 1, pp. 57-86).

Yildiz, H.E. (2014), "Not all differences are the same: dual roles of status and cultural distance in sociocultural integration in cross-border M\&A", Journal of International Management, Vol. 20 No. 1, pp. 25-37.

Yip, G. and McKern, B. (2014), "Innovation in emerging markets - the case of China", International Journal of Emerging Markets, Vol. 9 No. 1, pp. 2-10.

Zhang, Y. and Filippov, S. (2009), "Internationalization of Chinese firms in Europe", Working Paper No. 041, Unu-Merit Maastricht, Maastricht.

Zhang, Y. and Roelfsema, H. (2014), "Unravelling the complex motivations behind China's outward FDI", Journal of the Asia Pacific Economy, Vol. 19 No. 1, pp. 89-100.

Zhao, J. and Ordonez de Pablos, P. (2010), "Chinese firms' outward direct investment: technological innovation mechanisms, organizational modes and improving strategies", Human Factors and Ergonomics in Manufacturing and Service Industries, Vol. 20 No. 2, pp. 149-160.

\section{Further reading}

Kuemmerle, W. (1996), "Home base and foreign direct investment in R\&D”, unpublished $\mathrm{PhD}$ dissertation, Harvard Business School, Boston, MA.

Wei, Y., Zheng, N., Liu, X. and Lu, J. (2014), "Expanding to outward foreign direct investment or not? A multi-dimensional analysis of entry mode transformation of Chinese private exporting firms", International Business Review, Vol. 23 No. 2, pp. 356-370.

\footnotetext{
About the authors

Professor Philippe Gugler is the Director of the Center for Competitiveness, Fribourg. Professor Philippe Gugler is the corresponding author and can be contacted at: philippe.gugler@unifr.ch Laura Vanoli is a PhD Student and a Research Assistant at the Center for Competitiveness, Fribourg.
}

For instructions on how to order reprints of this article, please visit our website: 